\title{
Intergenerational mobility, middle sectors and entrepreneurship in Uruguay
}

\author{
Gandelman, Néstor \\ Universidad ORT Uruguay \\ Robano, Virginia \\ The George Washington University \\ *
}

Agosto de 2012

\begin{abstract}
This paper estimates the relationship between parents' educational attainment and income and children's schooling in Uruguay between 1982 and 2010. This relationship is interpreted as a measure of intergenerational social mobility, and the paper reports evidence that it has decreased over time. The paper finds that the probability that the children of the more educated remain among the more educated has grown, with analogous results for the less educated. As a result, the improvements in education of the 1980s and 1990s were unevenly distributed, with a bias against the disadvantaged. The paper also finds that while entrepreneurship status and belonging to the middle class matter in terms of social mobility as measured by compulsory education, i.e., primary school and the first three years of secondary school, they do not have a notable effect on noncompulsory education, i.e., the last three years of secondary school and higher.
\end{abstract}

JEL codes: I24. J62. L26

Keywords: intergenerational social mobility, entrepreneurship, middle class

Documento de Investigación, Nro. 77, agosto 2012. Universidad ORT Uruguay.

Facultad de Administración y Ciencias Sociales. ISSN 1688-6275

\footnotetext{
* The authors thank Daniel Bukstein, Eduardo Lora, Francesca Castellani, and participants in the IDB organized discussion workshop "Strengthening Mobility and Entrepreneurship: A Case for the Middle Classes" for their helpful comments and suggestions. All errors and omissions are solely the authors'.
} 


\section{Introduction}

The relationship between the middle sectors and entrepreneurship remains a subject of debate. Some argue that the middle sectors are important for development because they are the source for entrepreneurship and innovation and they create employment and productivity growth (Acemoglu and Zilibotti 1997). Successful entrepreneurs move up the income and social ladders, while unsuccessful entrepreneurs are at risk for moving down those ladders. If the middle sectors are truly the cradle of entrepreneurship, they could be the group experiencing the largest social mobility within a country. Some authors do not believe this to be the case, and they emphasize that the middle sectors are the country's well-paid salaried workers (Banerjee and Duflo 2007). A distinction can be made between "opportunity entrepreneurs," that is, those who see an unexploited business opportunity, and "necessity entrepreneurs," that is, those who are mostly associated with the informal sector, with fewer possibilities of generating positive externalities (Acs 2006). Necessity entrepreneurs are less likely to find a reasonably wellpaying job in the labor market, so they end up self-employed in low-productivity activities. The expected social mobility of opportunity entrepreneurs and necessity entrepreneurs is different.

We use the term "middle sectors" rather than "middle class." The concept of class involves the perception of belonging to a group and homogeneity of characteristics, i.e., those related to and rewarded by the labor market, that are not necessarily present in a partition of the population by income ranking. The reference to middle sectors is not new in the literature; it has been used at least since Johnson (1958).

In this paper, we proxy intergenerational social mobility by measuring parents' schooling and income as an influence on children's schooling. The larger the influence, the higher the probability that differences in income and education will be perpetuated. We study social mobility by looking at the differences between sectors of society, i.e., disadvantaged, middle, and affluent, and we also examine the relationship between entrepreneurship and social mobility. We do so using data on Uruguay, a less-developed country with some particularly interesting characteristics for a study of middle sectors, entrepreneurship and social mobility. Traditionally, Uruguay has been considered a country with a strong and stable middle class comprising mostly European immigrants 
and their descendants. Many of these immigrant families have stories of social ascendance. Although the immigrants were in many cases scarcely educated, they managed to prosper, and their children's attainment far surpassed that of their parents.

The public school system initially developed in the final decades of the $19^{\text {th }}$ century acted as a melting pot; differences in social origin were somewhat diluted. In more recent decades, there have been signs that social interaction has worsened, with increased segregation and marginalization of the poor. The latest international educational performance tests administered to Uruguayan students-the PISA-showed disappointing results. Educational performance in public schools has worsened compared to outcomes obtained in the growing private education sector. Bukstein and Sapelli (2011) find that between the 2003 and 2009 PISA rounds, there was an increase in opportunity inequality. Vega and Petrow (2008) show that along with income inequality, Uruguay has extreme educational inequality. This evidence suggests that the education system is no longer compensating for differences in origin. What is more, the education system might actually be perpetuating these differences.

The paper proceeds as follow. In Section 2 we present our data and basic definitions. Section 3 presents the methodology we use to construct a social mobility index from the impact of parents' background on the educational outcomes of their children. It also shows how this methodology can be extended to address the impact of entrepreneurship on differences among social sectors. Section 4 reports descriptive results and Section 5 the mobility results. Section 6 concludes.

\section{Data and Definitions}

\subsection{Data}

The data come from household surveys (Encuesta Continua de Hogares-ECH) conducted by the National Institute of Statistics (INE). These surveys, conducted annually, ask about household composition, including the age, gender, educational attainment, and labor market variables of household members, among other indicators. We accessed data from 1982 to 2010. The household surveys cover the capital city of Montevideo and other urban areas, i.e., areas with more than 5000 inhabitants, in the rest of the country. The INE only began gathering information for rural settings in 2006; for 
comparison reasons these settings are not covered in this paper.

\subsection{Definitions}

\subsubsection{Middle Sectors}

We explore three alternative definitions of middle sector.

First, we define the middle sector as those individuals whose household per capita income is between 50 and 150 percent of the median per capita income. We refer to those below 50 percent of the median per capita income as the "disadvantaged" sector and those above 150 percent as the "affluent" sector. These are relative measures of social sectors closely related to income inequality. In a hypothetical country where everyone has the same income, all are considered to belong in the middle sector, irrespective of income, whether US\$1 or US\$10,000 per month.

Second, we define middle sectors as those with purchasing power parity (PPP), adjusted per capita daily income between US\$10 and US\$50,at constant 2005prices. ${ }^{1}$ Those below the US\$10 threshold are the disadvantaged and those above US\$50 are the affluent. This is an absolute measure of social sectors that aims at capturing the risk of falling into poverty as proposed by Lopez-Calva and Ortiz-Juarez (2011).

Third, we follow Esteban et al. (1999) and implement a polarization methodology where individuals are assigned to sectors of society to minimize income differences between sectors as proxied by the Gini coefficient. ${ }^{2}$ The number of sectors is exogenous to the methodology. We use three.

\subsubsection{Entrepreneurship}

What constitutes an entrepreneur is a critical definition. We are interested in the effects of opportunity entrepreneurs and not necessity entrepreneurs. Using household surveys, this distinction is empirically difficult to make because there are no good proxy variables for making this classification that are uncorrelated with income and income mobility.

In this paper, the operational definition of an entrepreneur is an individual in charge of his or her own business who employs at least one person. Those who are in charge of their business but who do not have employees, i.e., the self-employed, are probably necessity entrepreneurs and are therefore not included in our definition of

\footnotetext{
${ }^{1}$ The PPP conversion factor is the local currency unit per US\$. Source: Word Development Indicators.

2 There is a freely available Stata module that implements this methodology (Distributive Analysis Stata Package). http://dasp.ecn.ulaval.ca/modules.htm. Araar and Duclos (2007).
} 
entrepreneurs. ${ }^{3}$ We consider a household as belonging to the entrepreneurial sector when its main source of income comes from the entrepreneurial activity of one of its members.

\section{Social Mobility Methodology}

\subsection{The Impact of Parent's Schooling on Children's Schooling}

We compute a social mobility index (SMI) that measures the inter-generational transmission of educational attainment between parents and children. This methodology was initially developed by Behrman et al. (1999). ${ }^{4}$ It provides a way of measuring social mobility in cases where surveys that follow individuals through time are unavailable. The SMI calculates an indicator of future opportunities for children in families, using household income and parental education. The basic idea underlying this methodology posits that if family background, i.e., parents' educations and income, is important in determining $^{5}$ opportunities for children, then social differences are perpetuated, i.e., there will be a low level of inter-generational mobility within the society. But if family background is not decisive in explaining educational outcomes, the education system is functioning as a homogenizing device, allowing for greater social mobility.

The proxy to measure future opportunities is the schooling gap (SG), that is, the difference between the years of schooling that a child should have, according to his or her age, and the actual years of schooling that the child has. The SG measures years of missing education. It is calculated as the difference between the child's age minus 6 minus years of education.

The first step in computing the SMI index is to run a set of ordinary least squares (OLS) regressions on all school age children. We run one regression for each year. The main covariates are those related to family background, i.e., per capita household income, $y$, and maximum educational attainment by the parents, $E$, along with a broad set of

\footnotetext{
${ }^{3}$ Bukstein and Gandelman (2011) show that among the self-employed there are two groups. Those without a fixed workplace are necessity entrepreneurs and those with a fixed workplace behave in some ways as necessity and in other ways as opportunity entrepreneurs.

${ }^{4}$ See also Azevedo and Bouillon (2010) for a review of Latin American evidence on inter-generational social mobility.

${ }^{5}$ We speak of determining in a loose sense. Since we lack an identification strategy, the relationship between family background and children's education outcome should not be interpreted in causal terms. See Haveman and Wolfe (1995) for a review of the older literature and Holmlund et al. (2011) for the newer literature, including limits to causal inference.
} 
covariates, $X$, that might affect the child's schooling gap, i.e., whether there are siblings in the household, the birth order of the child for whom the SG is calculated, whether the household head is a female, the age of the household head, and whether the child lives in a single parent household.

$$
S G_{i}=\alpha+\beta_{0} E_{i}+\beta_{1} y_{i}+X_{i}^{\prime} \Pi+u_{i}
$$

We then apply the Fields (2003) decomposition, which builds on the Shapley (1953) income decomposition, implemented by Shorrocks (1982), which decomposes inequality in the schooling gap into a factor inequality weight (FIW) for each of the explanatory variables. This decomposition has several properties: in particular, it gives a unique decomposition rule, irrespective of the inequality index used, i.e., whether it is the variance of the dependent variable as in this paper, the Gini index, and so on, provided that the inequality index is continuous, symmetric, and takes the value of zero when all observations are identical. The sum of all weighting factors adds up the R-squared coefficient of the regression. After some additional manipulation, the FIW can be expressed as the product of the estimated coefficient of each variable, its standard deviation, and the correlation coefficient between the variable and the schooling gap, divided by the standard deviation of the schooling gap itself. For example, the FIW for educational attainment is calculated as:

$$
S_{E_{t}}=\frac{\beta 0 \sigma\left(E_{t}\right) \cdot \operatorname{cor} r\left[E_{t} ; S G_{t}\right]}{\sigma(S G t)}
$$

The SMI is the difference between 1 minus the proportion of the SG explained by the family background.

$$
S M I_{t}=1-\frac{\beta_{0} \sigma\left(E_{t}\right) \operatorname{corr}\left(E_{t}, S G_{t}\right)}{\sigma\left(S G_{t}\right)}-\frac{\beta_{1} \sigma\left(y_{t}\right) \operatorname{corr}\left(y_{t}, S G_{t}\right)}{\sigma\left(S G_{t}\right)}
$$

We compute the SMI for two age subgroups: 6-15 and 16-23. In Uruguay, all children must attend school until the third year of secondary education. This defines the first age group. The second age group is for individuals that go beyond this mandatory educational level. Since we need data on parents' education, we could consider only those individuals who live with their parents. This may induce certain biases in our computation since those living with their parents, especially for the older group, are not likely a random sample of the population of their cohort. In our estimations, the proportion of children aged 16-23 that are living with their parents is 88 percent. 


\subsection{Differences in the Social Mobility Index}

The previous methodology could be extended to address the impact of belonging to a certain group, e.g., middle sectors or entrepreneurs. In order to do that, we have to add several interactions to proxy for social sectors and entrepreneurship status to equation (1). The augmented equations with only the entrepreneurship interaction, only the social sector interactions, and both interactions at the same time, are respectively:

$$
\begin{aligned}
& S G_{i}=\alpha+\beta_{0} E_{i}+\beta_{1} y_{i}+\beta_{0 e} E_{i} \mathrm{I}_{e i}+\beta_{1 e} y_{i} \mathrm{I}_{e i}+X^{\prime}{ }_{i} \Pi+\gamma_{e} \mathrm{I}_{e i}+u_{i} \\
& S G_{i}=\alpha+\beta_{0} E_{i}+\beta_{1} y_{i}+\beta_{0 m} E_{i} \mathrm{I}_{M i}+\beta_{1 m} y_{i} \mathrm{I}_{M i}+\beta_{0 a} E_{i} \mathrm{I}_{A i}+\beta_{1 a} y_{i} \mathrm{I}_{A i} \\
& +X^{\prime}{ }_{i} \Pi+\gamma_{m} \mathrm{I}_{M i}+\gamma_{a} \mathrm{I}_{A i}+u_{i} \\
& S G_{i}=\alpha+\beta_{0} E_{i}+\beta_{1} y_{i}+\beta_{0 m} E_{i} \mathrm{I}_{M i}+\beta_{1 m} y_{i} \mathrm{I}_{M i}+\beta_{0 a} E_{i} \mathrm{I}_{A i}+\beta_{1 a} y_{i} \mathrm{I}_{A i} \\
& +\beta_{0 e} E_{i} \mathrm{I}_{e i}+\beta_{1 e} y_{i} \mathrm{I}_{e i}+X^{\prime}{ }_{i} \Pi+\gamma_{m} \mathrm{I}_{M i}+\gamma_{a} \mathrm{I}_{A i}+\gamma_{e} \mathrm{I}_{e i}+u_{i}
\end{aligned}
$$

where $\mathrm{I}_{M}$ and $\mathrm{I}_{A}$ are indicator functions whether the children $i$ belong to the middle or affluent sectors respectively, and $\mathrm{I}_{e}$ indicates that the household's main income is provided by an entrepreneur.

After equation 6 is estimated, the impact of parents' income and education on the SG are:

$$
\begin{aligned}
& \frac{\partial S G}{\partial y}=\hat{\beta}_{1}+\hat{\beta}_{1 m} \mathrm{I}_{M}+\hat{\beta}_{1 a} \mathrm{I}_{A}+\hat{\beta}_{1 e} \mathrm{I}_{e} \\
& \frac{\partial S G}{\partial E}=\hat{\beta}_{0}+\hat{\beta}_{0 m} \mathrm{I}_{M}+\hat{\beta}_{0 a} \mathrm{I}_{A}+\hat{\beta}_{0 e} \mathrm{I}_{e}
\end{aligned}
$$

The impact of family background depends on the social sector and entrepreneurship status of the household. In this manner, we can compute the SMI for specific groups of interest. For instance, the SMI for middle sector entrepreneurs is: 


$$
\begin{aligned}
& S M I_{t}=1-\frac{\beta_{0} \sigma\left(E_{t}\right) \operatorname{corr}\left(E_{t}, S G_{t}\right)}{\sigma\left(S G_{t}\right)}-\frac{\beta_{1} \sigma\left(y_{t}\right) \operatorname{corr}\left(y_{t}, S G_{t}\right)}{\sigma\left(S G_{t}\right)} \\
& -\frac{\beta_{0 m} \sigma\left(m_{t} E_{t}\right) \operatorname{corr}\left(m_{t} E_{t}, S G_{t}\right)}{\sigma\left(S G_{t}\right)}-\frac{\beta_{1 m} \sigma\left(m_{t} y_{t}\right) \operatorname{corr}\left(m_{t} y_{t}, S G_{t}\right)}{\sigma\left(S G_{t}\right)} \\
& -\frac{\beta_{0 e} \sigma\left(e_{t} E_{t}\right) \operatorname{corr}\left(e_{t} E_{t}, S G_{t}\right)}{\sigma\left(S G_{t}\right)}-\frac{\beta_{1 e} \sigma\left(e_{t} y_{t}\right) \operatorname{corr}\left(e_{t} y_{t}, S G_{t}\right)}{\sigma\left(S G_{t}\right)}
\end{aligned}
$$

In the results section, we introduce the interactions by steps: first, only entrepreneurship (equation 7), second, only social sectors (equation 8), and finally, the full set (equation 9).

\section{Descriptive Results}

\subsection{Middle Sectors}

Table 1 and Figures 1 to 3 report the structure of the Uruguayan population by social sector. As previously explained, the three measures are not identical. According to the "absolute" measure, the middle sector is composed of those households with daily income per capita between US $\$ 10$ and US $\$ 50$ for 2005,PPP adjusted. According to the "relative" definition based on the median for 2005, the thresholds that define the middle sector are $\$ 4.6$ and $\$ 13.7$. The polarization definition implies for 2005 that the middle sector is between $\$ 7.3$ and $\$ 17.9$. The absolute measure based on the vulnerability approach includes in the middle sector individuals that are substantially better off than in the other two measures. This is consistent with what Lopez-Calva and Ortíz-Juarez report that they find for Chile, Mexico, and Peru: that there is a substantial portion of the population not included in the middle sector, since they are at risk of falling into poverty but are not considered poor in their countries. In the rest of the paper, whenever we disaggregate results by social sector, we do so by the absolute sector classification based on PPP per capita income. In interpreting the results, we keep in mind that the chosen definition of the middle sector encompasses the wealthiest set of individuals.

Although there are differences between the three methodologies, all of them suggest that Uruguay has a large middle sector. Consistent with our findings, the Organisation for Economic Co-operation and Development (OECD) (2011) reports that Uruguay has the largest middle sector among all Latin American countries.

In the almost three decades covered by this study, the Uruguayan middle sector 
makes up between 48 and 57 percent of the population, according to the relative sector definition. This measure, albeit stable through the period, started to decrease with the recession of 1999, and reached its smallest proportion in 2006. From 2006 onwards, its tendency reverted and by 2010 it comprised 57 percent of the population. The disadvantaged sector has been growing slowly since the 1990s, but its tendency has also reverted during the more recent years covered in this study, achieving a minimum size for the whole period of study of 15 percent of the population.

The absolute sector classification based on PPP per capita income is more volatile. It shows a very small affluent sector that reached its maximum in 2010, with 6 percent of the population. The middle sectors experienced a sharp increase since the second half of the 1980s, concomitant with a decrease in the disadvantaged. This is known as the democratic recovery period. By 1999, the size of the middle class stabilized at around 56 percent of the population. The middle and disadvantaged sectors followed the business cycle, showing a decrease and increase respectively in the late 1990s and the beginning of the new century just as the country's per capita GDP did.

The polarization index methodology shows the most stable picture. The middle sector comprises between 40 and 41 percent of the population, which is about the same size as the disadvantaged and twice the affluent. ${ }^{6}$

\footnotetext{
${ }^{6}$ In 2006 the figure for the affluent and the disadvantaged is strange given the stability of the series. In that year the INE expanded considerably the sample.
} 


\begin{tabular}{|c|c|c|c|c|c|c|c|c|c|}
\hline & \multicolumn{9}{|c|}{$\begin{array}{l}\text { Table1. Population by Social Sectors, } 1982 \text { to } 2010 \\
\text { (in percentages) }\end{array}$} \\
\hline & \multicolumn{9}{|c|}{ Social sectors defined by: } \\
\hline & \multicolumn{3}{|c|}{ Distance to the median income } & \multicolumn{3}{|c|}{ Daily PPP dollars } & \multicolumn{3}{|c|}{ Optimal polarization index bounds } \\
\hline & Disadvantaged & Middle & Affluent & Disadvantaged & Middle & Affluent & Disadvantaged & Middle & Affluent \\
\hline 1982 & 21 & 48 & 31 & 44 & 53 & 3 & 38 & 40 & 22 \\
\hline 1983 & 20 & 51 & 30 & 43 & 54 & 3 & 37 & 40 & 24 \\
\hline 1984 & 20 & 50 & 30 & 58 & 41 & 2 & 36 & 40 & 24 \\
\hline 1985 & 18 & 55 & 28 & 53 & 46 & 1 & 35 & 41 & 24 \\
\hline 1986 & 21 & 50 & 29 & 49 & 48 & 3 & 37 & 40 & 23 \\
\hline 1987 & 18 & 54 & 28 & 50 & 49 & 2 & 36 & 40 & 23 \\
\hline 1988 & 18 & 53 & 29 & 47 & 50 & 3 & 38 & 41 & 21 \\
\hline 1989 & 18 & 55 & 27 & 48 & 50 & 2 & 37 & 41 & 22 \\
\hline 1990 & 18 & 55 & 27 & 51 & 47 & 2 & 37 & 41 & 22 \\
\hline 1991 & 17 & 56 & 27 & 46 & 52 & 2 & 38 & 41 & 21 \\
\hline 1992 & 17 & 56 & 28 & 46 & 51 & 3 & 37 & 40 & 22 \\
\hline 1993 & 18 & 55 & 27 & 39 & 59 & 3 & 36 & 41 & 23 \\
\hline 1994 & 18 & 55 & 27 & 37 & 59 & 4 & 37 & 41 & 22 \\
\hline 1995 & 18 & 54 & 28 & 39 & 57 & 3 & 37 & 40 & 23 \\
\hline 1996 & 18 & 53 & 28 & 40 & 56 & 3 & 36 & 41 & 23 \\
\hline 1997 & 19 & 53 & 28 & 41 & 56 & 3 & 37 & 41 & 22 \\
\hline 1998 & 18 & 51 & 30 & 37 & 59 & 4 & 35 & 41 & 24 \\
\hline 1999 & 21 & 51 & 28 & 40 & 56 & 5 & 40 & 41 & 19 \\
\hline 2000 & 21 & 51 & 27 & 40 & 56 & 4 & 39 & 41 & 19 \\
\hline 2001 & 21 & 50 & 28 & 45 & 52 & 4 & 40 & 41 & 19 \\
\hline 2002 & 22 & 49 & 28 & 51 & 46 & 3 & 40 & 40 & 19 \\
\hline 2003 & 21 & 51 & 28 & 60 & 39 & 2 & 40 & 41 & 19 \\
\hline 2004 & 22 & 50 & 28 & 59 & 39 & 2 & 40 & 41 & 19 \\
\hline 2005 & 22 & 51 & 28 & 56 & 42 & 2 & 39 & 41 & 20 \\
\hline 2006 & 19 & 44 & 37 & 56 & 41 & 3 & 34 & 40 & 26 \\
\hline 2007 & 22 & 44 & 33 & 48 & 47 & 5 & 38 & 41 & 21 \\
\hline 2008 & 17 & 53 & 29 & 39 & 57 & 4 & 37 & 41 & 21 \\
\hline 2009 & 17 & 54 & 30 & 33 & 61 & 5 & 38 & 41 & 21 \\
\hline 2010 & 15 & 57 & 28 & 27 & 67 & 6 & 38 & 41 & 21 \\
\hline
\end{tabular}



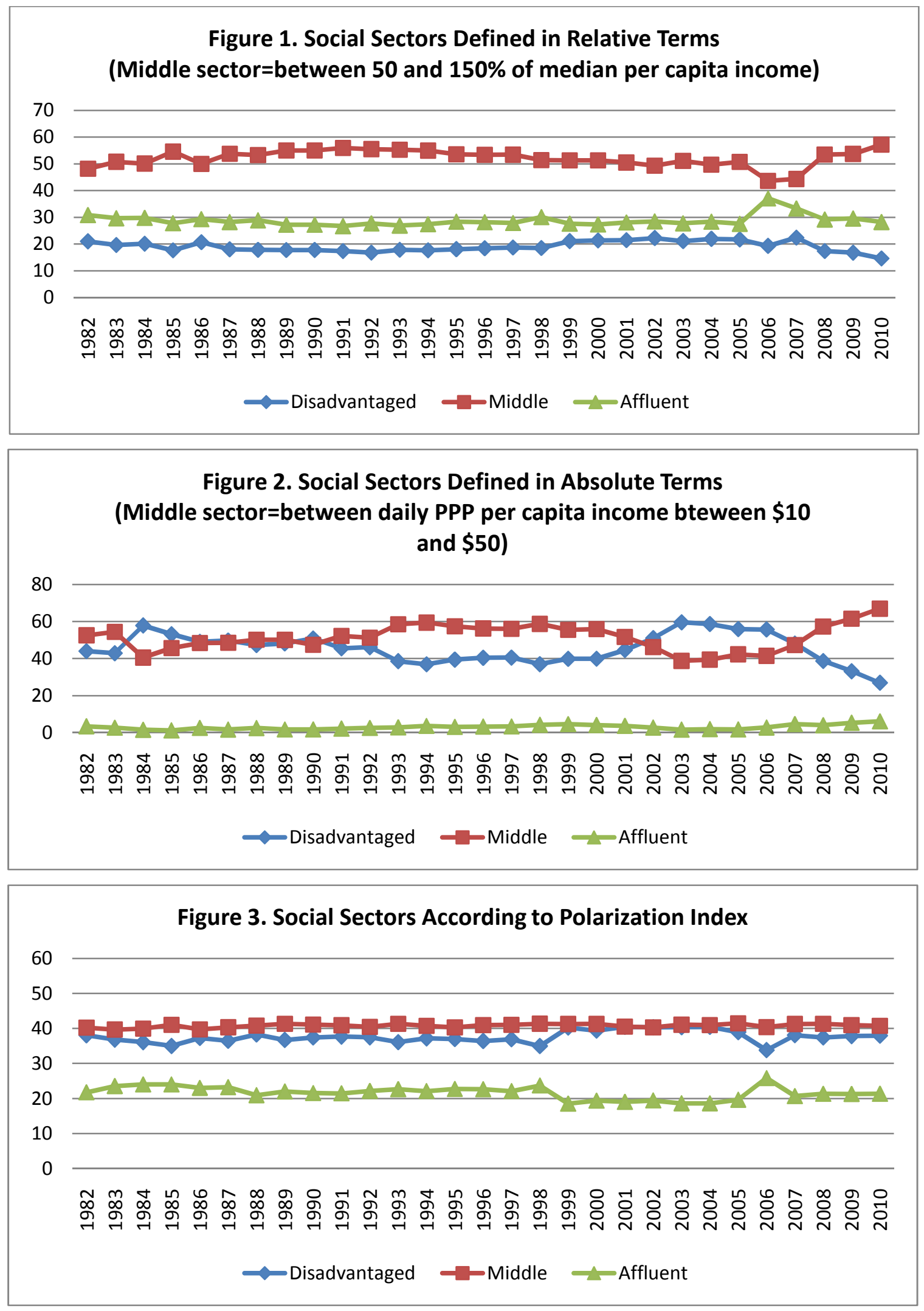
Table 2 reports socio-demographic differences between social sectors defined according to the US\$10 and US\$50 thresholds. Between 1984 and 2010 there was an improvement in the average years of education for the population as a whole, but the distribution of this improvement was uneven. While the increase in years of education for the average individual among the disadvantaged is less than one, for the middle sectors the increase is 1.7 years, and for the affluent the increase is more than two and a half years. In 2010, on average, those in the middle sector finished primary school and completed three years of secondary school. In Uruguay, this is the minimum mandatory education. Affluent individuals on average completed secondary school and began tertiary education.

The average age has increased for all social sectors but mostly for the affluent. This is in part due to improvements in life expectancy and to a continuous non-random emigration process. The affluent and middle sectors are much older than the disadvantaged are. This might be due to their access to better health care and healthier living environments.

The average number of children has decreased in the period under study for the disadvantaged but has remained almost unchanged for the middle and affluent sectors. The fecundity rate for the disadvantaged sector is more than two times the fecundity rate for the middle sector.

Finally, the geographic distribution of the population did not suffer important changes. The affluent mostly dwell within the capital city, while the disadvantaged live in the rest of the country. This result should be qualified by the fact that our income measure does not control for the different costs of living in Montevideo and the rest of the country.

\begin{tabular}{|l|ccccccccc|}
\hline \multicolumn{2}{|c|}{ Table 2. Socio- demographic Characteristics of Social Sectors (Adult Population) } \\
\hline & \multicolumn{2}{|c}{ Disadvantaged } & \multicolumn{3}{c|}{ Middle } & \multicolumn{2}{c|}{ Affluent } & \multicolumn{2}{c|}{ All } \\
& 1984 & 2010 & 1984 & 2010 & 1984 & 2010 & 1984 & 2010 \\
\hline Years of Education & 6.28 & 7.10 & 7.83 & 9.53 & 10.58 & 13.35 & 7.13 & 9.29 \\
Age & 41.49 & 42.21 & 48.20 & 48.66 & 52.88 & 54.19 & 44.99 & 47.68 \\
Gender (female=1) & $54 \%$ & $54 \%$ & $54 \%$ & $54 \%$ & $58 \%$ & $56 \%$ & $54 \%$ & $54 \%$ \\
Number of children & 1.04 & 0.76 & 0.32 & 0.32 & 0.10 & 0.13 & 0.67 & 0.40 \\
Capital city (Montevideo=1) & $31 \%$ & $29 \%$ & $52 \%$ & $44 \%$ & $65 \%$ & $72 \%$ & $42 \%$ & $43 \%$ \\
\hline
\end{tabular}

Source: Authors' calculations based on household surveys 


\subsection{Entrepreneurship}

Table 3 presents the percentage of entrepreneurs by income sector for two extreme years in this study. It is difficult to evaluate what is a low or high level of entrepreneurship for any given country. The main income provider is an entrepreneur in only 5 percent of the households in Uruguay. Kantis et al. (2012), using the same operational definitions that we use, find that Uruguay has about the same amount of entrepreneurship activity as Brazil, a bit more than Argentina, but less than Ecuador and El Salvador.

Figure 4 presents the evolution of entrepreneurship in absolute and percentage terms by social sector over time. The distribution of entrepreneurs among social sectors is uneven, as is the proportion of entrepreneurs within sectors. Most entrepreneurs belong to the middle sector, i.e., more than 70 percent in 2010, but entrepreneurship is proportionately stronger in the affluent sector. In relation to sector size, only between 1-2 percent of the disadvantaged are entrepreneurs while entrepreneurship among the affluent is at least 14 percent, with a maximum in 1992 of 29 percent. Besides the differences in level, entrepreneurship is procyclical for the affluent and middle sectors. There is a noticeable decrease after 1999 , with a low point in 2003, after which a recovery in entrepreneurship activity starts following the recovery of national growth.

Table 3. Size of Entrepreneur Status by Social Sector, 1982 and 2010

\begin{tabular}{|l|ccccccccc|}
\hline & \multicolumn{2}{|c}{ Disadvantaged } & \multicolumn{2}{c}{ Middle } & \multicolumn{2}{c}{ Affluent } & \multicolumn{2}{c|}{ All } \\
& 1984 & 2010 & 1984 & 2010 & 1984 & 2010 & 1984 & 2010 \\
\hline Cases (unweighted) & 660 & 409 & 1,978 & 4,100 & 173 & 1,072 & 2,811 & 5,581 \\
Cases (weighted) & 3,043 & 4,199 & 51,960 & 54,759 & 85,208 & 74,218 & 140,211 & 133,176 \\
\% of social sector & $1.9 \%$ & $1.5 \%$ & $7.7 \%$ & $5.8 \%$ & $16.3 \%$ & $15.3 \%$ & $4.5 \%$ & $5.3 \%$ \\
\hline
\end{tabular}

Source: Authors' calculations based on household surveys. 


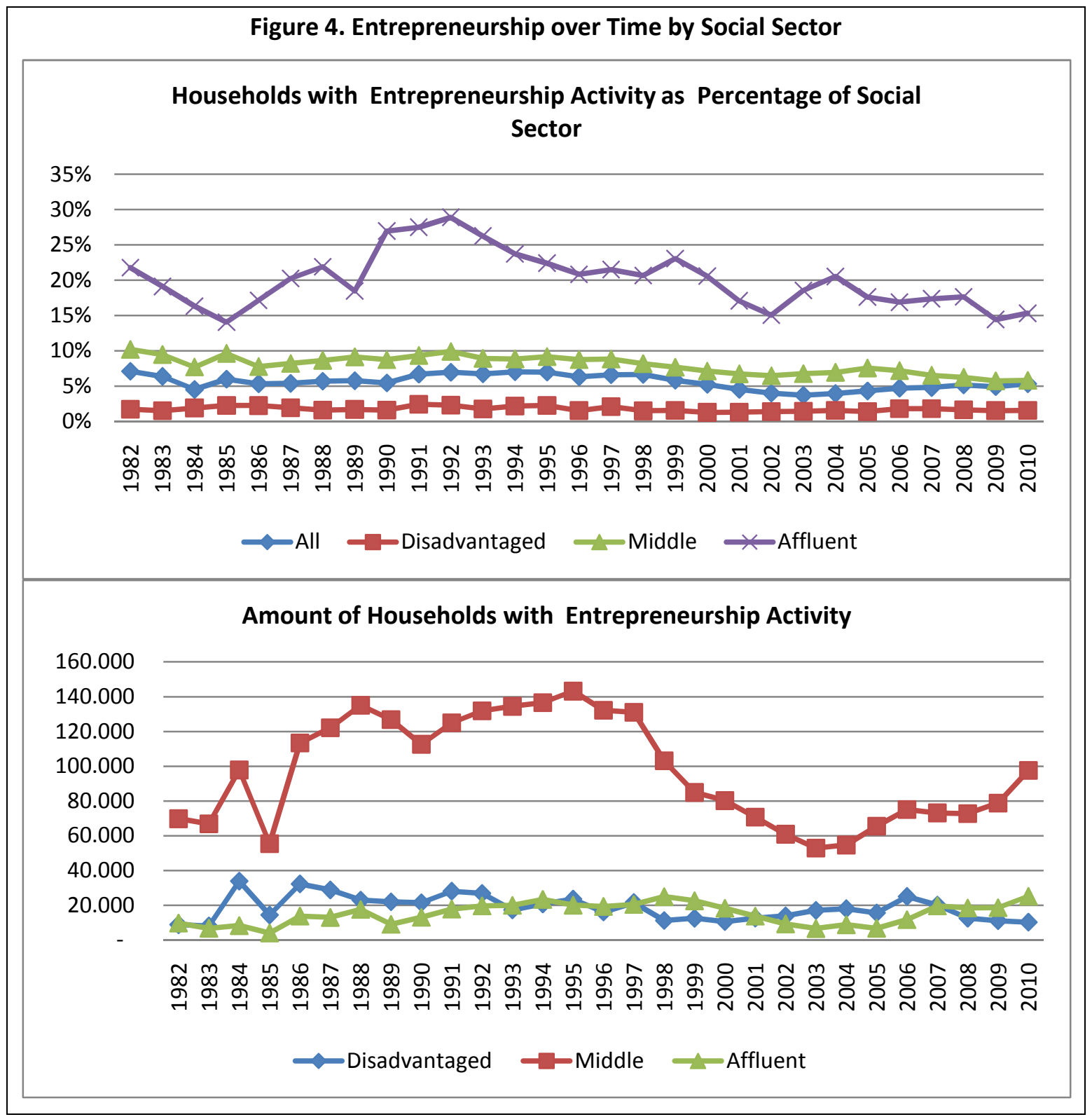

Table 4 reports several socio-demographic characteristics of entrepreneurs and the rest of the working population. Entrepreneurs have on average 1.8more years of education than the rest of the population. In 2010, they were also somewhat older than nonentrepreneurs. This may be the case for multiple reasons. On the one hand, it is possible that it takes time until an individual is able to start his or her own business, and the first working experiences of people are in jobs for others, rather than in their own business. Alternatively, some individuals inherit a family business. They work in the family business for several years until their older family members retire, and then they take over. 


\begin{tabular}{|lcccc|}
\hline \multicolumn{5}{|c|}{ Table 4. Socio-demographic Characteristics of Households by Entrepreneurship } \\
(individuals aged 18-65 years) \\
\hline \multicolumn{4}{c}{ Not entrepreneur } & Entrepreneur \\
& 1984 & 2010 & 1984 & 2010 \\
\hline Years of Education & 7.38 & 9.70 & 9.18 & 11.51 \\
Age & 40.03 & 40.90 & 40.31 & 41.87 \\
Number of children & 0.77 & 0.49 & 0.77 & 0.45 \\
Capital city (Montevideo=1) & $41 \%$ & $42 \%$ & $51 \%$ & $39 \%$ \\
\hline
\end{tabular}

Source: Authors' calculations based on household surveys

\subsection{Education}

The improvement in education over time previously mentioned is shown in Table 5. Older individuals of all social sectors have less education than younger individuals. But improvement in education is not homogenous among sectors. The average improvement in education is $0.8,1.9$, and 3.2 years for the disadvantaged, the middle, and the affluent sectors, respectively. As a result of these uneven outcomes, differences in education have widened between sectors for all age groups. The larger differences are in the 46-55 age range. In 1984, an affluent individual had 3.4 more years of education than a middle sector individual, and 5.5 more years than a disadvantaged individual. In 2010 these differences were 4.3 and 7.3, respectively. These are signs of increased social segmentations that vitiate social mobility. Without considering the quality of the education received, we report that there are quantity differentials that have been widening the gap between social sectors. Table 5 suggests that the public education system is not successful in reducing opportunity inequality between social sectors.

\begin{tabular}{|c|c|c|c|c|c|c|c|c|c|c|c|c|}
\hline \multicolumn{13}{|c|}{ Table 5. Mean Education by Age and Sector } \\
\hline & \multicolumn{4}{|c|}{ Average } & \multirow{2}{*}{\multicolumn{2}{|c|}{$26-35$}} & \multirow{2}{*}{\multicolumn{2}{|c|}{$36-45$}} & \multirow{2}{*}{\multicolumn{2}{|c|}{ 46-55 }} & \multirow{2}{*}{\multicolumn{2}{|c|}{$56-65$}} \\
\hline & & & & & & & & & & & & \\
\hline & 1984 & 2010 & 1984 & 2010 & 1984 & 2010 & 1984 & 2010 & 1984 & 2010 & 1984 & 2010 \\
\hline Disadvantaged & 6.6 & 7.4 & 7.9 & 8.3 & 7.4 & 7.7 & 6.4 & 7.4 & 5.2 & 6.9 & 4.5 & 5.9 \\
\hline Middle & 8.4 & 10.3 & 10.2 & 11.2 & 10.3 & 11.1 & 8.8 & 10.7 & 7.3 & 10.0 & 6.1 & 8.6 \\
\hline Affluent & 11.0 & 14.1 & 11.6 & 14.0 & 13.0 & 15.0 & 10.9 & 14.7 & 10.7 & 14.2 & 10.2 & 13.3 \\
\hline
\end{tabular}

Source: Authors' calculations based on household surveys.

Table 6 presents a transition matrix for some selected years. This transition matrix shows 
the probability of educational attainment that children have, conditioned on their parent's educational attainment. Since Uruguayan household surveys do not gather information about the parents' background, we construct it only for children between the ages of 19 and 23 living with their parents. The surveys show that 81 percent of individuals in that age range live with their parents. We recognize that there may be some bias because of the 19 percent of individuals that we cannot consider in this matrix. ${ }^{7}$ We divide educational attainment into three categories: primary education or less, some secondary school, completion of secondary school, and more.

The top left figure in each matrix shows the percentage of students who have parents with the lowest educational attainment whose children have similar levels. The bottom right figure shows the percentage of students who have parents with the highest educational attainment whose children have similar levels. Over time, both of these numbers have been increasing. This is a sign of diminishing educational mobility.

The matrices also show upward and downward mobility. In 1985, 77 percent of children whose parents completed primary education and 21 percent of children whose parents had some secondary education outperformed their parents. Also in 1985, 5 percent of children whose parents had some secondary education only finished primary school, and 55 percent of children whose parents had secondary or higher education did not complete secondary school.

\footnotetext{
${ }^{7}$ Although the age range is the same, the average age of children living with their parents is 20.8 while the average age of those not living with their parents is 21.6. In addition, the children are less educated, having 9.4 vs. 10.4 years of education. Females tend to get married earlier than males. Females represent 44 percent of "children" living with their parents and 65 percent of those not living with them.
} 
Documento de Investigación - ISSN 1688-6275 - No. 77 - 2012 - Gandelman, N., Robano, V.

\begin{tabular}{|c|c|c|c|c|}
\hline \multicolumn{5}{|c|}{ Table 6. Education Transition Matrix by Year (Children Aged 19-23) } \\
\hline \multirow[b]{3}{*}{1985} & & \multicolumn{3}{|c|}{ Education of Children } \\
\hline & & Primary or less & Some secondary & Secondary and higher \\
\hline & & & & \\
\hline \multirow{3}{*}{$\begin{array}{r}\text { Parent's } \\
\text { education }\end{array}$} & Primary or less & $24 \%$ & $68 \%$ & $9 \%$ \\
\hline & Some secondary & $5 \%$ & $74 \%$ & $21 \%$ \\
\hline & Secondary and higher & $2 \%$ & $53 \%$ & $44 \%$ \\
\hline \multicolumn{5}{|l|}{1990} \\
\hline \multirow{3}{*}{$\begin{array}{l}\text { Parent's } \\
\text { education }\end{array}$} & Primary or less & $24 \%$ & $69 \%$ & $7 \%$ \\
\hline & Some secondary & $5 \%$ & $76 \%$ & $18 \%$ \\
\hline & Secondary and higher & $2 \%$ & $54 \%$ & $45 \%$ \\
\hline \multicolumn{5}{|l|}{1995} \\
\hline \multirow{3}{*}{$\begin{array}{r}\text { Parent's } \\
\text { education }\end{array}$} & Primary or less & $28 \%$ & $64 \%$ & $9 \%$ \\
\hline & Some secondary & $9 \%$ & $70 \%$ & $21 \%$ \\
\hline & Secondary and higher & $2 \%$ & $48 \%$ & $50 \%$ \\
\hline \multicolumn{5}{|l|}{2000} \\
\hline \multirow{3}{*}{$\begin{array}{l}\text { Parent's } \\
\text { education }\end{array}$} & Primary or less & $31 \%$ & $58 \%$ & $11 \%$ \\
\hline & Some secondary & $9 \%$ & $67 \%$ & $24 \%$ \\
\hline & Secondary and higher & $2 \%$ & $48 \%$ & $50 \%$ \\
\hline \multicolumn{5}{|l|}{2005} \\
\hline \multirow{3}{*}{$\begin{array}{l}\text { Parent's } \\
\text { education }\end{array}$} & Primary or less & $30 \%$ & $61 \%$ & $9 \%$ \\
\hline & Some secondary & $8 \%$ & $67 \%$ & $25 \%$ \\
\hline & Secondary and higher & $1 \%$ & $47 \%$ & $53 \%$ \\
\hline \multicolumn{5}{|l|}{2010} \\
\hline \multirow{3}{*}{$\begin{array}{l}\text { Parent's } \\
\text { education }\end{array}$} & Primary or less & $29 \%$ & $63 \%$ & $8 \%$ \\
\hline & Some secondary & $10 \%$ & $69 \%$ & $22 \%$ \\
\hline & Secondary and higher & $1 \%$ & $39 \%$ & $60 \%$ \\
\hline
\end{tabular}

Source: Authors' calculations based on household surveys.

In Figure 5 we report an immobility index and in Figure 6 we report an upward and downward mobility index. Let $T$ be a $3 \times 3$ transition matrix, $T=\left[\begin{array}{ccc}t_{11} & t_{12} & t_{13} \\ t_{21} & t_{22} & t_{23} \\ t_{31} & t_{32} & t_{33}\end{array}\right]$ and $m_{i}$ the share of individuals with educational level $i$. The upward mobility index is the weighted sum of all the cells, showing children who have at least the same level of education as 
their parents divided by 3 , i.e., the three levels of educational attainment. The downward mobility index is analogous, but has cells that show that children have equal or worse educational attainment than their parents. The immobility index is the weighted sum of the diagonal cells divided by 3 . Formally:

$$
\begin{aligned}
& I_{u p}=\frac{1+t_{22} m_{2}+t_{23} m_{2}+t_{33} m_{3}}{3} \\
& I_{\text {down }}=\frac{t_{11} m_{1}+t_{21} m_{2}+t_{22} m_{2}+1}{2} \\
& I_{\text {immobility }}=\frac{t_{11} m_{1}+t_{22} m_{2}+t_{33} m_{3}}{3}
\end{aligned}
$$

The upward mobility index is the ex ante probability that children achieve at least their parents' educational attainment. The downward mobility index is the ex ante probability that children achieve equal or lower educational attainment as their parents. The immobility index is the probability that children have the same educational attainment as their parents.

Figure 5 shows a rising immobility trend, with a reversion from 2005 onward. Figure 6 shows a continuous but small improvement in the upward mobility index and no changes in the downward mobility index. In 2010, about 84 percent of children had at least the educational attainment of their parents while in 1982 the figure was 78 percent.

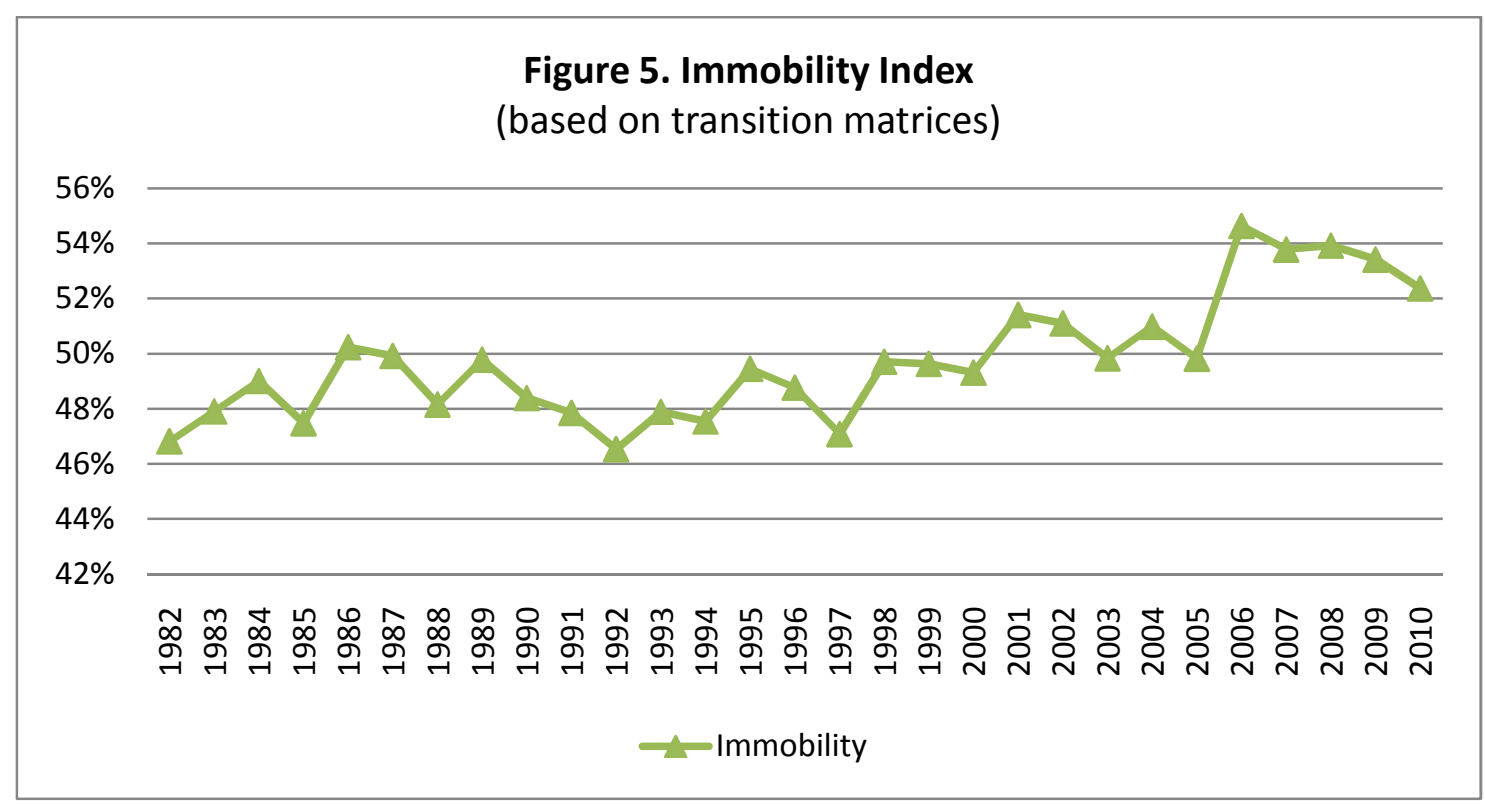




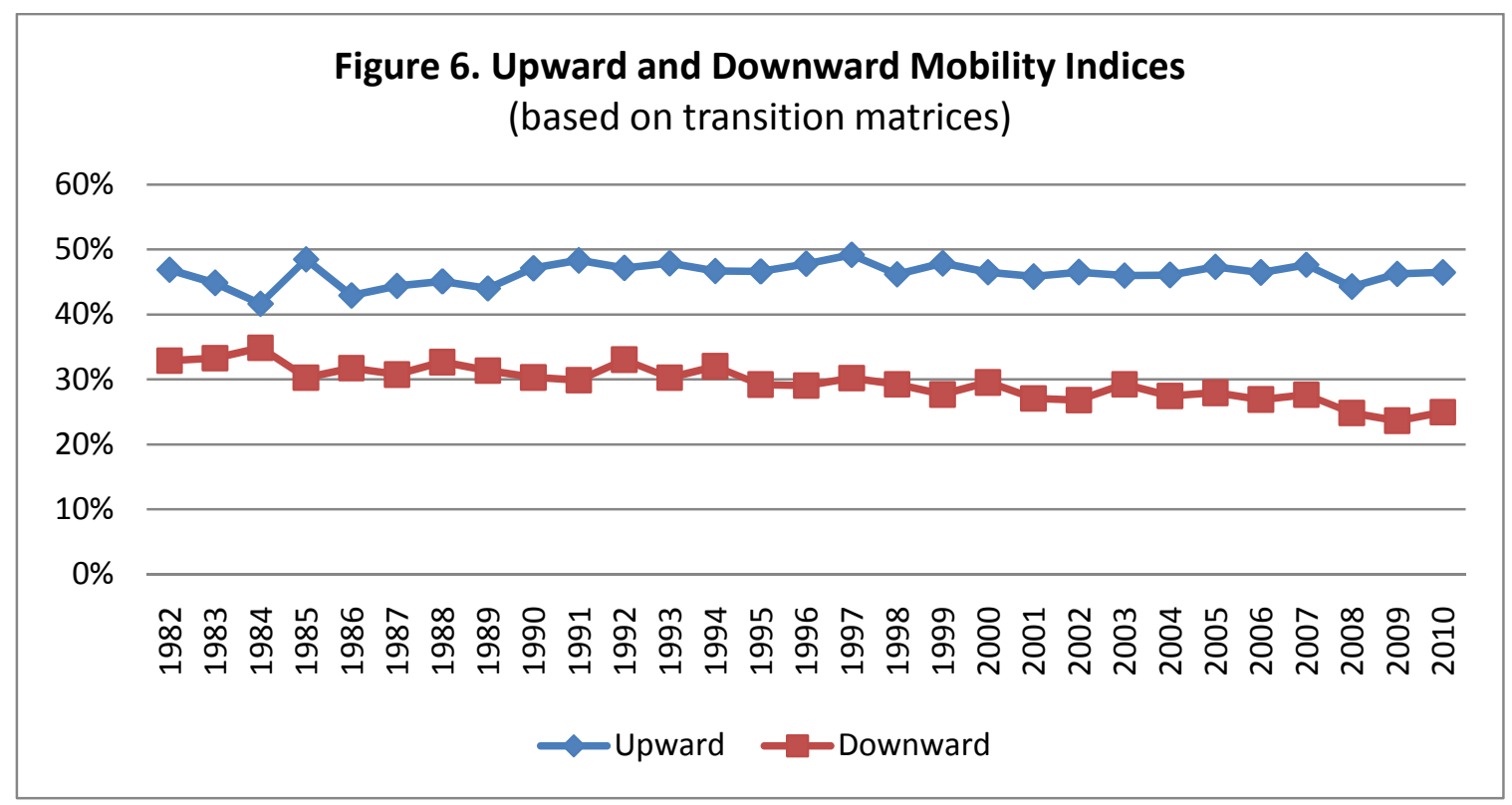

Each transition matrix, if repeated overt time, has an implicit steady-state distribution of educational attainment. If $p$ is a $3 \times 1$ vector reflecting the distribution of educational attainment, the steady-state distribution is such that

$$
p^{\prime}=p^{\prime} T
$$

Figure 7 presents the steady-state educational distribution implied by the transition matrices. Figure 8 presents the actual educational distributional matrix for people ages 19-23 who are still living with their parents. The number of people with higher education has been growing but seems to have stagnated during the second half of the 2000s. The percentage of people with higher and lower educational attainment in the actual distribution is somewhat lower and higher, respectively, than in the steady-state distribution. This is consistent with the positive upward mobility index reported in Figure 6. It means that the current situation repeated over time will produce an improvement in educational attainment. Nevertheless, this improvement is not very significant, since in the steady state fewer than 40 percent of the individuals between ages 19 and 23 would have completed secondary school. These figures place the largest enrollment and retention problems in the Uruguayan education system at the secondary level.

Figures 9 and 10 present the steady-state educational distribution for the 
disadvantaged and middle sectors. ${ }^{8}$ The picture shows improvement in access to higher education that appears in Figure 7. The steady-state distributional probabilities show that if the 2010 situation continues, close to 30 percent of the Uruguayan population will have at least completed secondary school. This 30 percent is a weighted average of different situations among social sectors: about 10 percent of disadvantaged, 35 percent of the middle sectors, and a great deal more for the affluent. At the other extreme, less than 10 percent of the maximum educational attainment for the Uruguayan population would be primary school. This 10 percent is concentrated in the disadvantaged sector, and it is almost nonexistent within the other sectors. The enrollment and retention problems of secondary school are greater for the disadvantaged sector but they are also significant for the middle sectors.

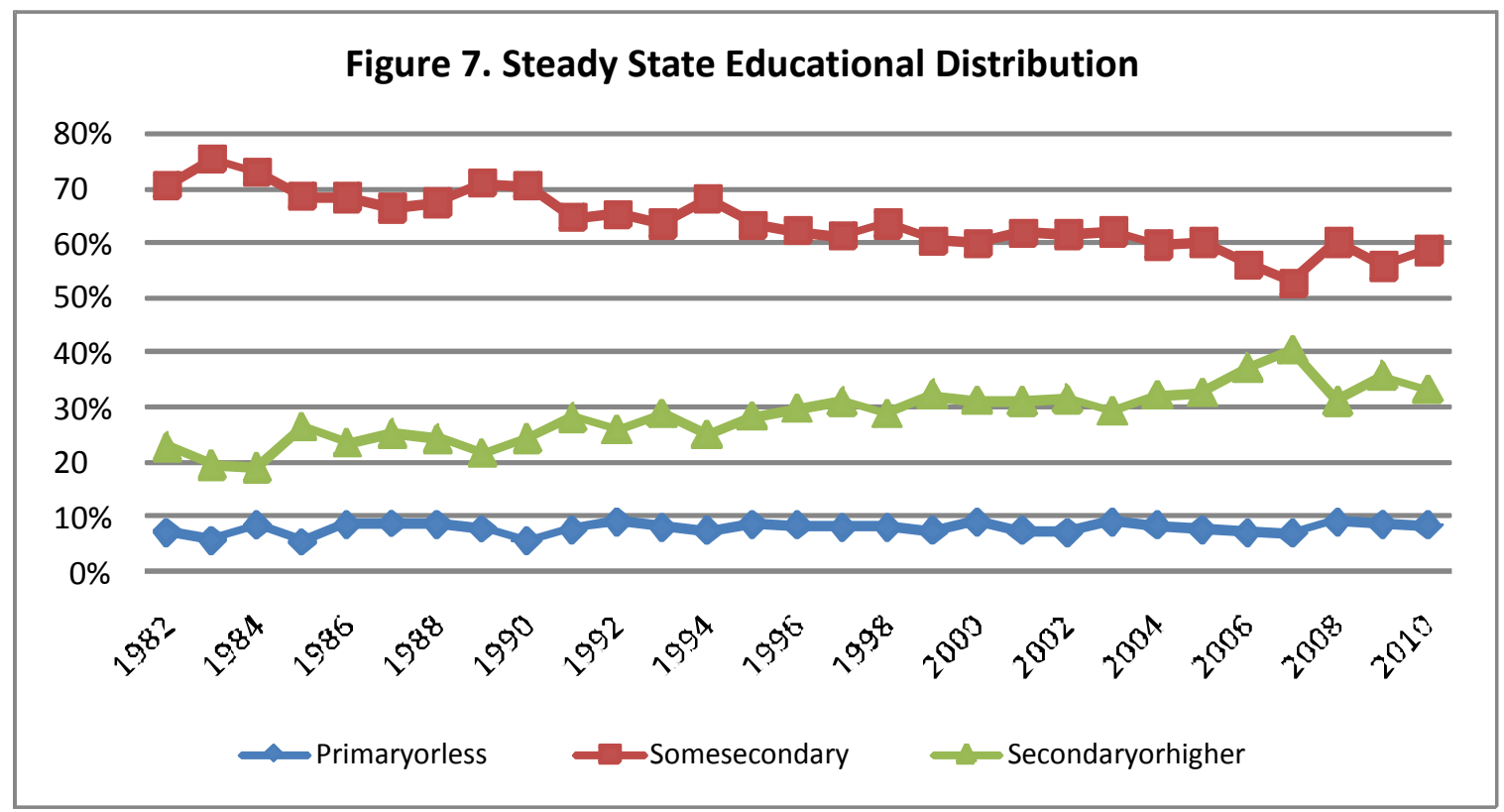

\footnotetext{
${ }^{8} \mathrm{We}$ do not present the steady-state distribution for the affluent sector because it is very volatile due to the small number of observations.
} 

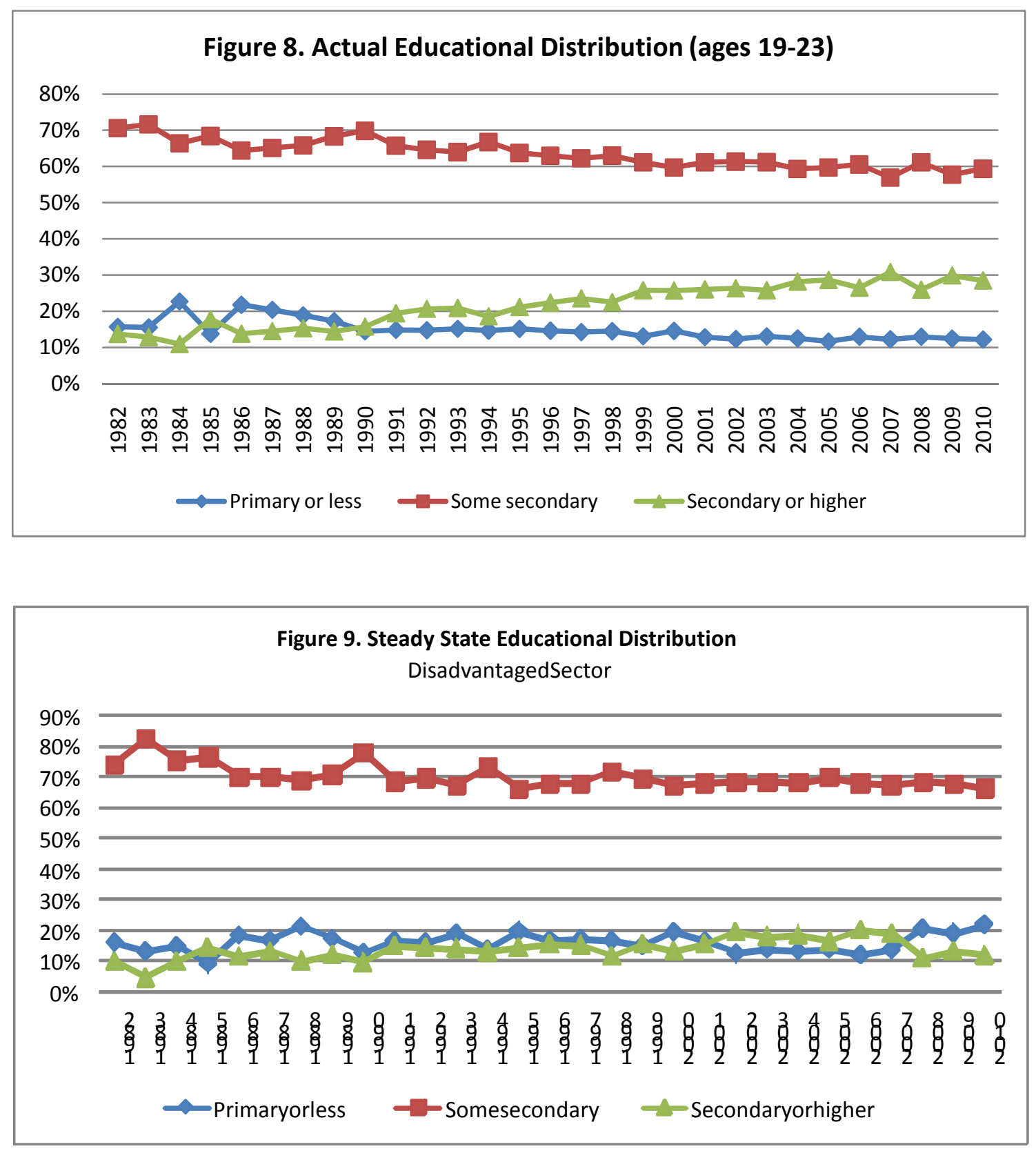


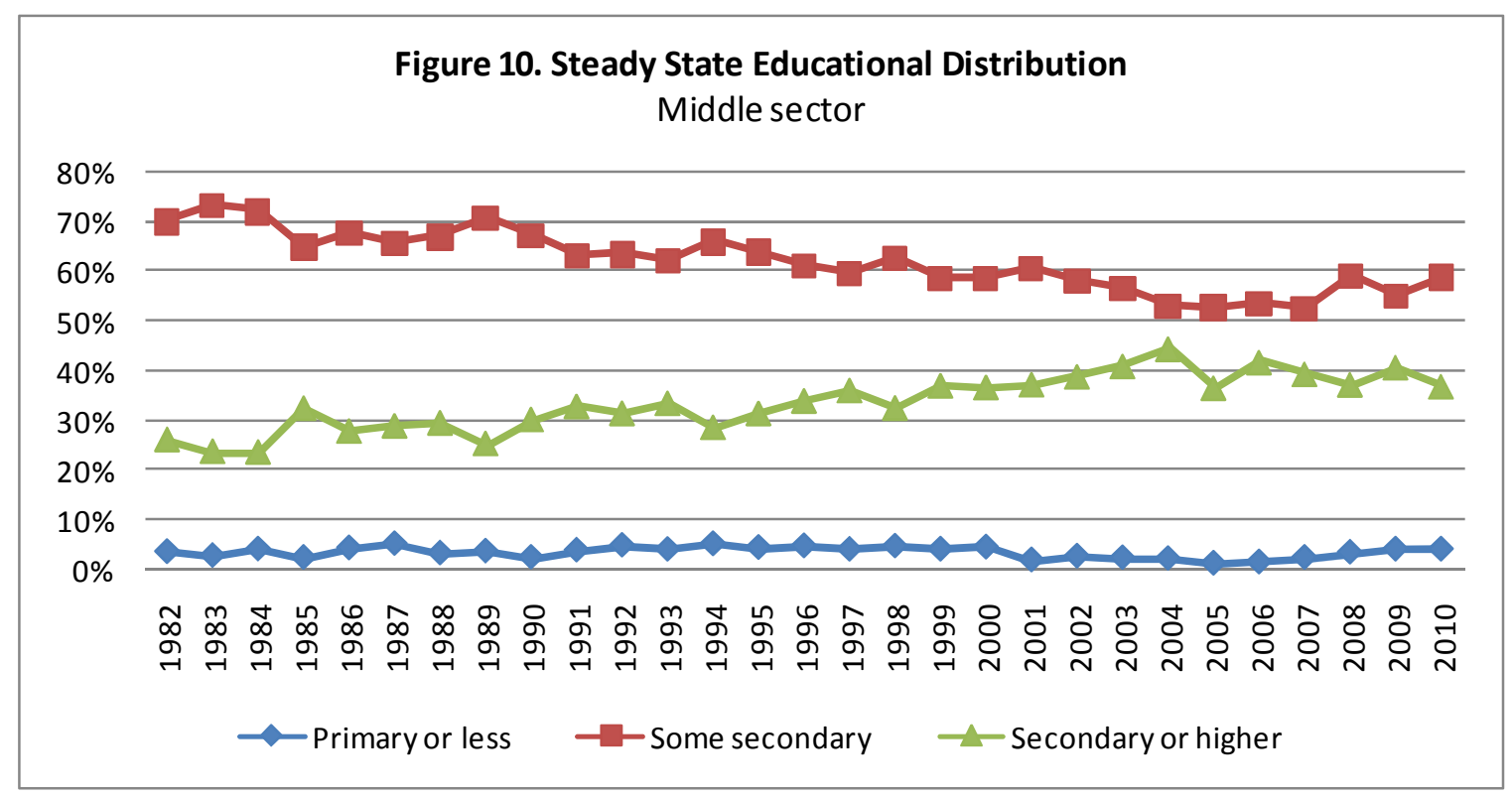

\section{Social Mobility Results}

Before presenting the results of the SMI, in Table 7 we present some descriptive statistics of the SG by social sector and entrepreneurship status. The upper part of the table shows the SG for children enrolled in mandatory education, i.e., ages 6-15. While in 1984 only children of disadvantaged sector entrepreneurs showed a SG smaller than the other sectors, in 2010 both middle and affluent sectors showed a significant difference in the SG, which in any case is small, i.e., less than one fifth of a year. The SG in the disadvantaged sector is much larger than it is for the middle and affluent sectors.

In the lower part of Table 7 is the SG for children in non-mandatory education ages 16-23). There we can see significant differences for the disadvantaged and the middle sectors that have persisted since 1984. Among the more affluent individuals in society, there are no differences in SG that can be linked to entrepreneurship. Overall, children of entrepreneurs have a smaller SG. A likely explanation for this is that opportunity entrepreneurs pass their higher abilities on to their children. An alternative explanation is that the larger measurement error in entrepreneurs' income wrongly classifies some of them as middle sector even though their income levels are comparable to those in the affluent sector. As expected, the SG for non-mandatory education is smaller for affluent households, and the differences in SG between sectors are larger than in the mandatory years of education. This may happen because the children of the more 
affluent sectors have access to better quality schools that reduce their current SG and that give them a stronger background and motivation to continue on to tertiary education.

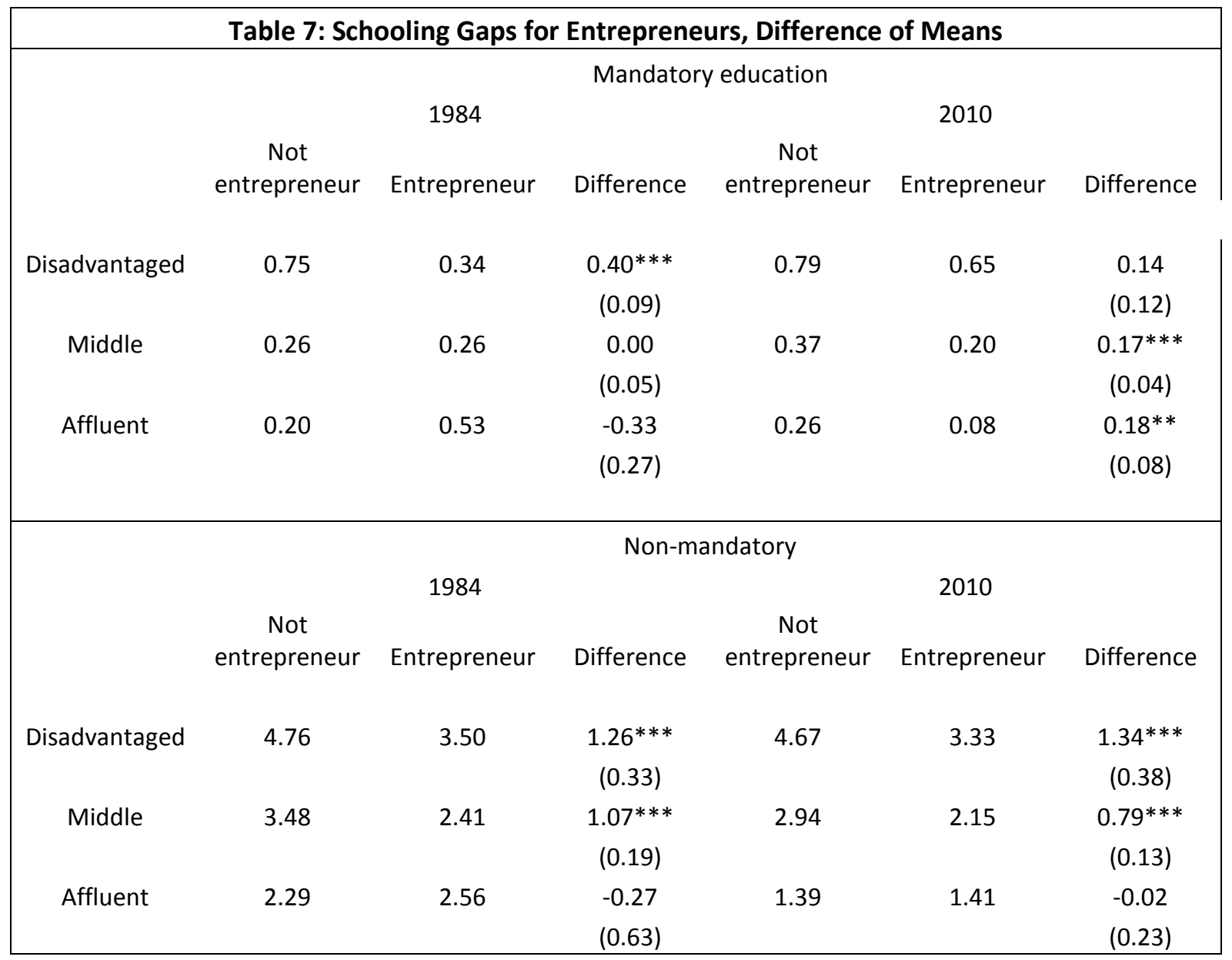

The results reported so far do not control for joint determination and for the impact of other family background characteristics. As an illustration of the regressions behind the SMI, we present in Table 8 the OLS estimation results of the SG for mandatory education on four sets of covariates for 2006. The first column shows the baseline estimation of the determinants of the SG with no distinction between entrepreneurship status and social sector corresponding to equation (1). It shows that both household income per capita and parental educational attainment are negatively correlated with the SG. The second column, equation 4, presents the determinants of the SG, distinguishing between entrepreneurs and others by incorporating a binary variable for entrepreneurs and relating this variable to parental income and educational attainment. The overall explanatory power of the family background characteristics does not vary with the inclusion of 
entrepreneurship status, although the interaction of these variables with entrepreneurship has a positive sign. This means that for entrepreneurs, family income and education have a weaker relationship to the SG. One more year of parental education results in 0.07 fewer years of SG for the average individual. One more year of parental education is associated with 0.05 fewer years of SG for households with entrepreneurship activity.

The third column, equation 5, considers social sectors and their interactions with family background. The coefficients on income and education increase in magnitude as they refer to the disadvantaged, the omitted category in this regression. The positive coefficients of the interactions imply that for the middle sector and the affluent sectors, the variables on family background have a lower weight in explaining SG than among the disadvantaged. For the middle sector, the impact of income and education on the SG is lower than for the disadvantaged sector; for the affluent sector, only education affects the SG. The fourth column, equation 6, presents both entrepreneurship and social sector interactions. The interaction coefficients are positive but not always significant; this may be due to correlation problems.

We present as an example the OLS estimation results for the SG for nonmandatory education in Table 9. The estimated coefficients of family background are almost four times higher for this case than for mandatory education.

Tables 10 and 11 present only the coefficients of interest, i.e., income, education, and the appropriate interactions for every year covered in this study. In the basic regressions for mandatory and non-mandatory education there are two clear patterns: the estimated coefficient of income decreases over time, while the coefficient of parents' educational attainment grows. Therefore, this information alone is insufficient to assess the impact of family background and inter-generational social mobility. In all regressions, the income and education variable have the expected sign and are significant. The size of the income coefficients in non-mandatory education is much greater than the education coefficient. This is reasonable since the SG in non-mandatory is larger than in mandatory education.

The impact of entrepreneurship on the SG, especially in non-mandatory education ages, is not obvious. It maybe that young adults whose parents are entrepreneurs quit school before age 23 to engage in the family business, or it may be that the children of 
entrepreneurs can afford to remain at home and continue studying. In Uruguay, the public school system developed early. In the final decades of the $19^{\text {th }}$ century, primary education was already considered mandatory, and it was free. Therefore, we would expect the effect of entrepreneurship and social differences to be larger for the SG of students ages 16-23. The net effect for entrepreneurs, i.e., the sum of the coefficient on household income plus the interaction of entrepreneurship with household income, gives a lower weight to family background characteristics. Thus, the social mobility index for entrepreneurs is higher.

The second vertical panels in Tables 10 and 11 show the interaction with entrepreneurship. In almost all years, at least one of the interactions with the two family background variables is statistically significant. In all cases, the interactions have a positive sign, suggesting that for entrepreneurs family background has a lower impact on SG than for non-entrepreneurs, i.e., inter-generational mobility captured by the SMI should be higher for entrepreneurs.

The third vertical panels show the interactions with social sectors. In almost every year, the interaction of middle sector is statistically significant for income or parental educational attainment. The signs in all cases are positive implying larger intergenerational mobility for the middle sector. The interaction with the affluent sector is in many cases not significant.

Contrary to what we expected, we found that there are more statistically significant interactions of entrepreneurship and middle sector for mandatory education than for non-mandatory education. This suggests that the institutional arrangements in Uruguay may be offering years of education for everyone, but there may be quality differences in the education, and that the children of entrepreneurs and the children of the more affluent are accessing higher quality education, perhaps from private schools that are inaccessible to disadvantaged families. We previously argued that the enrollment and retention problems of Uruguayan education system were in secondary school. One might naturally think that this has to do with what the secondary school is offering students. The results found for mandatory years of education for entrepreneurship and middle sectors, however, suggest a separate explanation. The problems in secondary school may lie in quality differentials during the earlier years of the student's formation, probably during 
primary school. These problems, therefore, are the cause of the differentials in intergenerational social mobility.

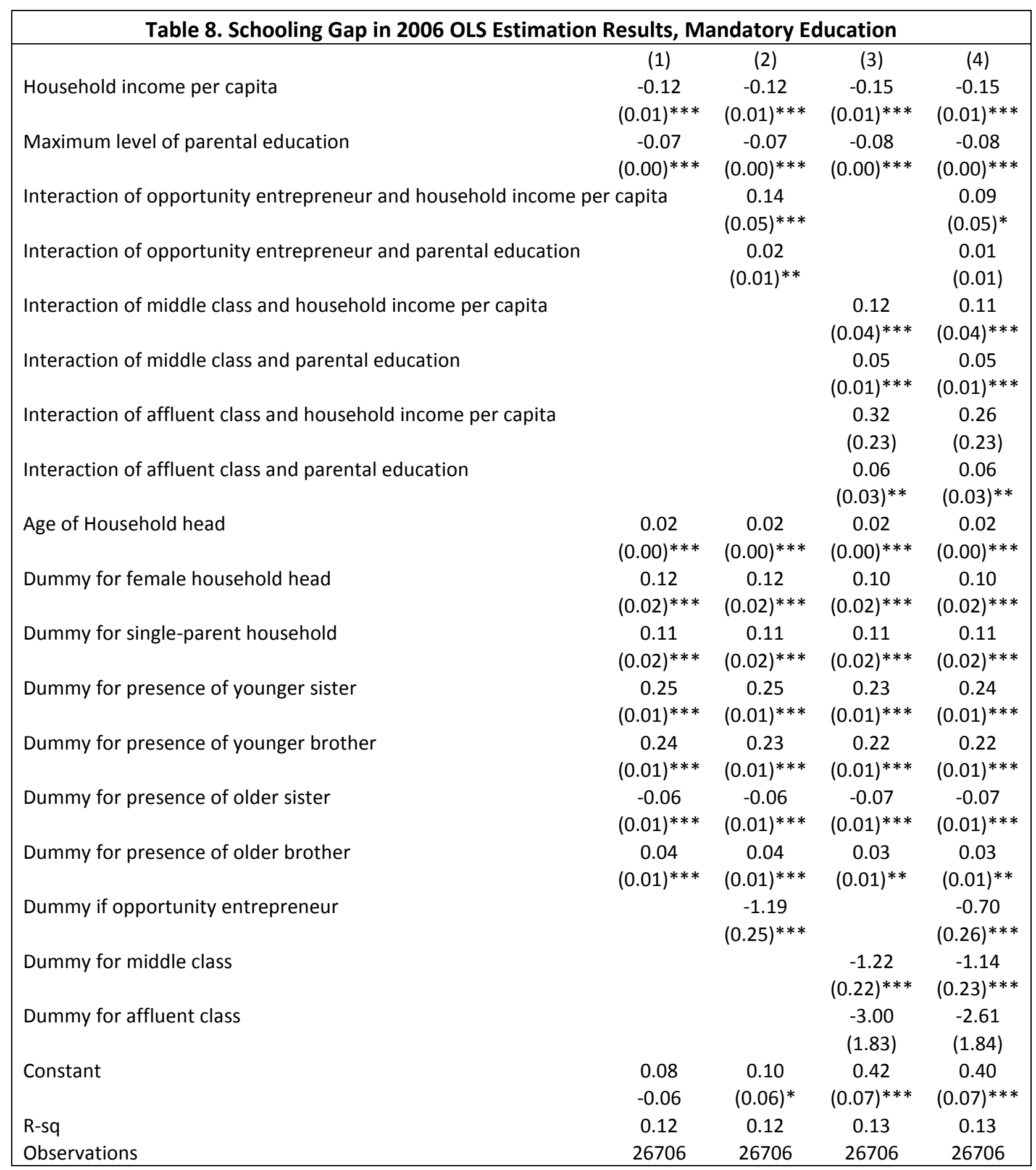

Standard errors in parentheses, * significant at $10 \% ;{ }^{* *}$ significant at $5 \% ;{ }^{* * *}$ significant at $1 \%$ 
Documento de Investigación - ISSN 1688-6275 - No. 77 - 2012 - Gandelman, N., Robano, V.

Table 9. Schooling Gap in 2006, OLS Estimation Results, Non-mandatory Education

\begin{tabular}{|c|c|c|c|c|}
\hline & (1) & (2) & (3) & (4) \\
\hline \multirow[t]{2}{*}{ Household per capita income } & -0.64 & -0.64 & -0.75 & -0.74 \\
\hline & $(0.03)^{* * *}$ & $(0.03)^{* * *}$ & $(0.05)^{* * *}$ & $(0.05)^{* * *}$ \\
\hline \multirow[t]{2}{*}{ Maximum level of parental education } & -0.28 & -0.28 & -0.31 & -0.31 \\
\hline & $(0.01)^{* * *}$ & $(0.01)^{* * *}$ & $(0.01)^{* * *}$ & $(0.01)^{* * *}$ \\
\hline \multirow{2}{*}{$\begin{array}{l}\text { Interaction of opportunity entrepreneur } \\
\text { and household income per capita }\end{array}$} & & 0.19 & & 0.00 \\
\hline & & $(0.13)$ & & $(0.14)$ \\
\hline \multirow{2}{*}{$\begin{array}{l}\text { Interaction of opportunity entrepreneur } \\
\text { and parental education }\end{array}$} & & 0.07 & & 0.05 \\
\hline & & $(0.03)^{* *}$ & & $(0.03)^{*}$ \\
\hline \multirow[t]{2}{*}{ Interaction of middle class and household income per capita } & & & 0.33 & 0.35 \\
\hline & & & $(0.11)^{* * *}$ & $(0.12)^{* * *}$ \\
\hline \multirow[t]{2}{*}{ Interaction of middle class and parental education } & & & 0.07 & 0.06 \\
\hline & & & $(0.02)^{* * *}$ & $(0.02)^{* * *}$ \\
\hline \multirow[t]{2}{*}{ Interaction of affluent class and household income per capita } & & & 0.60 & 0.59 \\
\hline & & & $(0.53)$ & $(0.53)$ \\
\hline \multirow[t]{2}{*}{ Interaction of affluent class and parental education } & & & 0.04 & 0.03 \\
\hline & & & $(0.08)$ & $(0.08)$ \\
\hline \multirow[t]{2}{*}{ Age of household head } & 0.07 & 0.07 & 0.07 & 0.07 \\
\hline & $(0.00)^{* * *}$ & $(0.00)^{* * *}$ & $(0.00)^{* * *}$ & $(0.00)^{* * *}$ \\
\hline \multirow[t]{2}{*}{ Dummy for female household head } & 0.48 & 0.46 & 0.45 & 0.43 \\
\hline & $(0.05)^{* * *}$ & $(0.05)^{* * *}$ & $(0.05)^{* * *}$ & $(0.05)^{* * *}$ \\
\hline \multirow[t]{2}{*}{ Dummy for single-parent household } & 0.05 & 0.05 & 0.05 & 0.05 \\
\hline & $(0.08)$ & $(0.08)$ & $(0.08)$ & $(0.08)$ \\
\hline \multirow[t]{2}{*}{ Dummy for presence of younger sister } & 0.30 & 0.30 & 0.27 & 0.27 \\
\hline & $(0.05)^{* * *}$ & $(0.05)^{* * *}$ & $(0.05)^{* * *}$ & $(0.05)^{* * *}$ \\
\hline \multirow[t]{2}{*}{ Dummy for presence of younger brother } & 0.43 & 0.43 & 0.40 & 0.40 \\
\hline & $(0.05)^{* * *}$ & $(0.05)^{* * *}$ & $(0.05)^{* * *}$ & $(0.05)^{* * *}$ \\
\hline \multirow[t]{2}{*}{ Dummy for presence of older sister } & -0.90 & -0.90 & -0.92 & -0.92 \\
\hline & $(0.07)^{* * *}$ & $(0.07)^{* * *}$ & $(0.07)^{* * *}$ & $(0.07)^{* * *}$ \\
\hline \multirow[t]{2}{*}{ Dummy for presence of older brother } & -0.74 & -0.74 & -0.76 & -0.76 \\
\hline & $(0.06)^{* * *}$ & $(0.06)^{* * *}$ & $(0.06)^{* * *}$ & $(0.06)^{* * *}$ \\
\hline \multirow[t]{2}{*}{ Dummy if opportunity entrepreneur } & & -2.21 & & -0.95 \\
\hline & & $(0.72)^{* * *}$ & & $(0.75)$ \\
\hline \multirow[t]{2}{*}{ Dummy for middle class } & & & -2.68 & -2.69 \\
\hline & & & $(0.65)^{* * *}$ & $(0.66)^{* * *}$ \\
\hline \multirow[t]{2}{*}{ Dummy for affluent class } & & & -4.12 & -3.83 \\
\hline & & & $(4.24)$ & $(4.24)$ \\
\hline \multirow[t]{2}{*}{ Constant } & 5.23 & 5.26 & 6.18 & 6.16 \\
\hline & $(0.23)^{* * *}$ & $(0.23)^{* * *}$ & $(0.30)^{* * *}$ & $(0.30)^{* * *}$ \\
\hline R-sq & 0.25 & 0.25 & 0.25 & 0.25 \\
\hline Observations & 16577 & 16577 & 16577 & 16577 \\
\hline
\end{tabular}

Standard errors in parentheses, ${ }^{*}$ significant at $10 \% ;{ }^{* *}$ significant at $5 \% ;{ }^{* * *}$ significant at $1 \%$ 
Table 10. Family Background Impact on SG (Mandatory Education)

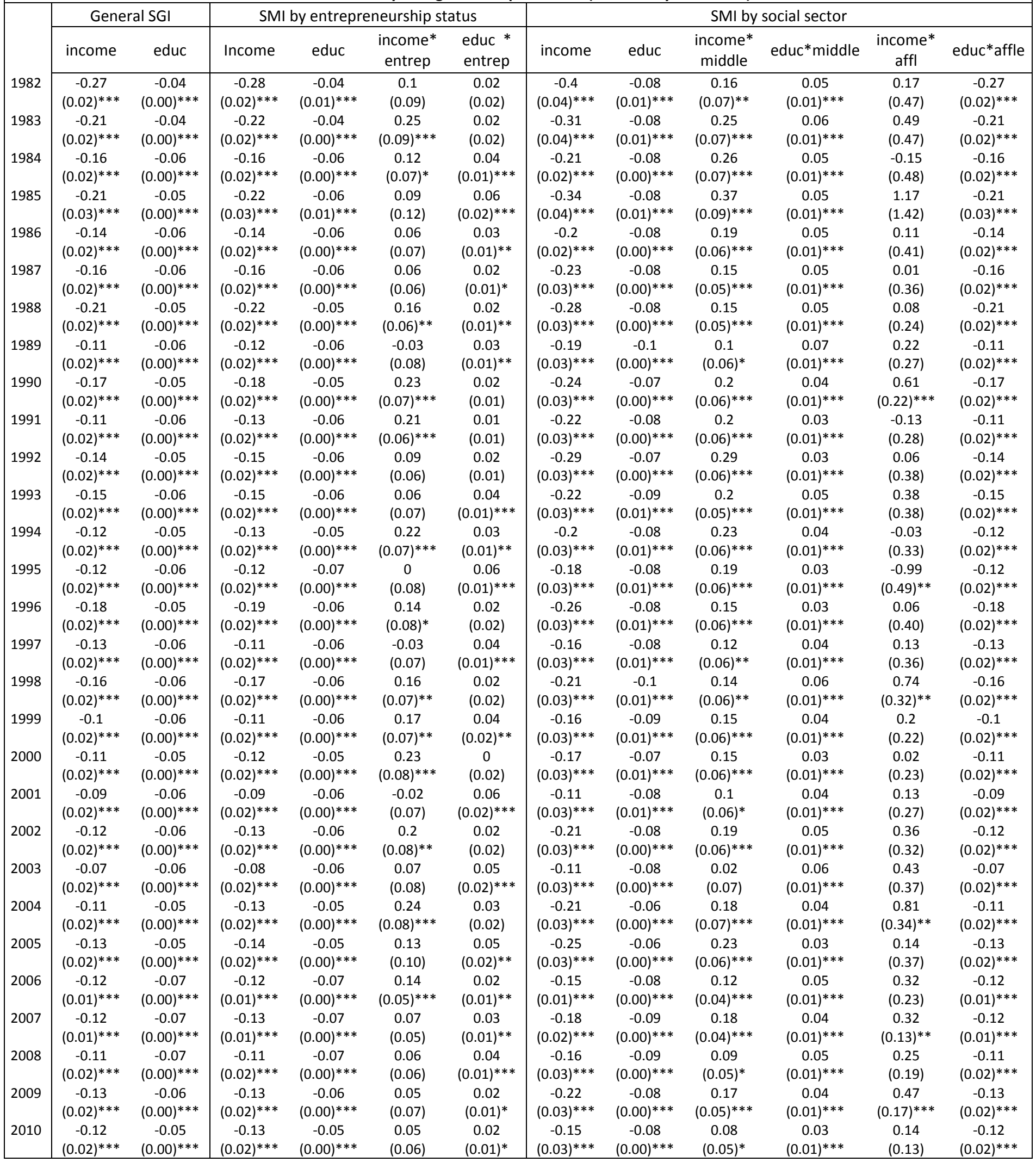

Standard errors in parentheses, ${ }^{*}$ significant at $10 \% ;{ }^{* *}$ significant at $5 \% ;{ }^{* * *}$ significant at $1 \%$ 


\begin{tabular}{|c|c|c|c|c|c|c|c|c|c|c|c|c|}
\hline \multirow[b]{3}{*}{1982} & \multicolumn{2}{|c|}{ General SGI } & \multicolumn{4}{|c|}{ SMI by entrepreneurship status } & \multicolumn{6}{|c|}{ SMI by social sector } \\
\hline & Income & education & income & education & $\begin{array}{c}\text { income* } \\
\text { entrep }\end{array}$ & $\begin{array}{l}\text { educ * } \\
\text { entrep }\end{array}$ & income & education & $\begin{array}{l}\text { income* } \\
\text { middle }\end{array}$ & educ*middle & $\begin{array}{c}\text { income* } \\
\text { affl }\end{array}$ & educ*affle \\
\hline & $\begin{array}{c}-0.92 \\
(0.07)^{* * *}\end{array}$ & $\begin{array}{c}-0.17 \\
(0.02)^{* * *}\end{array}$ & $\begin{array}{c}-0.91 \\
(0.07)^{* * *}\end{array}$ & $\begin{array}{c}-0.17 \\
(0.02)^{* * *}\end{array}$ & $\begin{array}{c}0.32 \\
(0.27)\end{array}$ & $\begin{array}{c}0.03 \\
(0.05)\end{array}$ & $\begin{array}{c}-1.08 \\
(0.13)^{* * *}\end{array}$ & $\begin{array}{c}-0.25 \\
(0.03)^{* * *}\end{array}$ & $\begin{array}{c}0.55 \\
(0.23)^{* *}\end{array}$ & $\begin{array}{c}0.1 \\
(0.03)^{* * *}\end{array}$ & $\begin{array}{c}1.05 \\
(0.92)\end{array}$ & $\begin{array}{c}0.13 \\
(0.08)^{*}\end{array}$ \\
\hline 1983 & $\begin{array}{c}-0.93 \\
(0.08)^{* * *}\end{array}$ & $\begin{array}{c}-0.2 \\
(0.02)^{* * *}\end{array}$ & $\begin{array}{c}-0.94 \\
(0.09)^{* * *}\end{array}$ & $\begin{array}{c}-0.21 \\
(0.02)^{* * *}\end{array}$ & $\begin{array}{c}0.75 \\
(0.31)^{* *}\end{array}$ & $\begin{array}{c}0.1 \\
(0.05)^{* *}\end{array}$ & $\begin{array}{c}-0.98 \\
(0.16)^{* * *}\end{array}$ & $\begin{array}{c}-0.25 \\
(0.03)^{* * *}\end{array}$ & $\begin{array}{c}0.26 \\
(0.24)\end{array}$ & $\begin{array}{c}0.06 \\
(0.03)^{*}\end{array}$ & $\begin{array}{c}3.21 \\
(2.01)\end{array}$ & $\begin{array}{c}0.19 \\
(0.11)^{*}\end{array}$ \\
\hline 1984 & $\begin{array}{c}-0.56 \\
(0.06)^{* * *}\end{array}$ & $\begin{array}{c}-0.24 \\
(0.01)^{* * *}\end{array}$ & $\begin{array}{c}-0.52 \\
(0.06)^{* * *}\end{array}$ & $\begin{array}{c}-0.24 \\
(0.01)^{* * *}\end{array}$ & $\begin{array}{c}0.2 \\
(0.23)\end{array}$ & $\begin{array}{c}0.11 \\
(0.04)^{* * *}\end{array}$ & $\begin{array}{c}-0.72 \\
(0.09)^{* * *}\end{array}$ & $\begin{array}{c}-0.29 \\
(0.02)^{* * *}\end{array}$ & $\begin{array}{c}0.78 \\
(0.19)^{* * *}\end{array}$ & $\begin{array}{c}0.07 \\
(0.02)^{* * *}\end{array}$ & $\begin{array}{c}1.34 \\
(1.28)\end{array}$ & $\begin{array}{c}0.14 \\
(0.08)^{*}\end{array}$ \\
\hline 1985 & $\begin{array}{c}-0.76 \\
(0.09)^{* * *}\end{array}$ & $\begin{array}{c}-0.21 \\
(0.02)^{* * *}\end{array}$ & $\begin{array}{c}-0.72 \\
(0.10)^{* * *}\end{array}$ & $\begin{array}{c}-0.23 \\
(0.02)^{* * *}\end{array}$ & $\begin{array}{c}0.64 \\
(0.36)^{*}\end{array}$ & $\begin{array}{c}0.25 \\
(0.05)^{* * *}\end{array}$ & $\begin{array}{c}-1.25 \\
(0.16)^{* * *}\end{array}$ & $\begin{array}{c}-0.27 \\
(0.03)^{* * *}\end{array}$ & $\begin{array}{c}0.66 \\
(0.28)^{* *}\end{array}$ & $\begin{array}{c}0.08 \\
(0.03)^{* *}\end{array}$ & $\begin{array}{c}1.15 \\
(1.65)\end{array}$ & $\begin{array}{c}0.14 \\
(0.15)\end{array}$ \\
\hline 1986 & $\begin{array}{c}-0.44 \\
(0.06)^{* * *}\end{array}$ & $\begin{array}{c}-0.24 \\
(0.01)^{* * *}\end{array}$ & $\begin{array}{c}-0.45 \\
(0.06)^{* * *}\end{array}$ & $\begin{array}{c}-0.23 \\
(0.01)^{* * *}\end{array}$ & $\begin{array}{c}0.36 \\
(0.22)^{*}\end{array}$ & $\begin{array}{l}-0.05 \\
(0.04)\end{array}$ & $\begin{array}{c}-0.49 \\
(0.11)^{* * *}\end{array}$ & $\begin{array}{c}-0.31 \\
(0.02)^{* * *}\end{array}$ & $\begin{array}{l}-0.04 \\
(0.18)\end{array}$ & $\begin{array}{c}0.12 \\
(0.02)^{* * *}\end{array}$ & $\begin{array}{c}0.91 \\
(0.96)\end{array}$ & $\begin{array}{l}-0.07 \\
(0.07)\end{array}$ \\
\hline 1987 & $\begin{array}{c}-0.53 \\
(0.06)^{* * *}\end{array}$ & $\begin{array}{c}-0.25 \\
(0.01)^{* * *}\end{array}$ & $\begin{array}{c}-0.49 \\
(0.06)^{* * *}\end{array}$ & $\begin{array}{c}-0.26 \\
(0.01)^{* * *}\end{array}$ & $\begin{array}{l}-0.11 \\
(0.22)\end{array}$ & $\begin{array}{c}0.1 \\
(0.04)^{* * *}\end{array}$ & $\begin{array}{c}-0.86 \\
(0.11)^{* * *}\end{array}$ & $\begin{array}{c}-0.32 \\
(0.02)^{* * *}\end{array}$ & $\begin{array}{c}0.56 \\
(0.18)^{* * *}\end{array}$ & $\begin{array}{c}0.09 \\
(0.02)^{* * *}\end{array}$ & $\begin{array}{l}-0.18 \\
(1.41)\end{array}$ & $\begin{array}{c}0.13 \\
(0.09)\end{array}$ \\
\hline 1988 & $\begin{array}{c}-0.7 \\
(0.06)^{* * *}\end{array}$ & $\begin{array}{c}-0.23 \\
(0.01)^{* * *}\end{array}$ & $\begin{array}{c}-0.69 \\
(0.06)^{* * *}\end{array}$ & $\begin{array}{c}-0.23 \\
(0.01)^{* * *}\end{array}$ & $\begin{array}{c}0.2 \\
(0.21)\end{array}$ & $\begin{array}{c}0.07 \\
(0.04)^{*}\end{array}$ & $\begin{array}{c}-0.9 \\
(0.12)^{* * *}\end{array}$ & $\begin{array}{c}-0.31 \\
(0.02)^{* * *}\end{array}$ & $\begin{array}{c}0.55 \\
(0.18)^{* * *}\end{array}$ & $\begin{array}{c}0.11 \\
(0.02)^{* * *}\end{array}$ & $\begin{array}{c}1.27 \\
(0.84)\end{array}$ & $\begin{array}{c}0.22 \\
(0.07)^{* * *}\end{array}$ \\
\hline 1989 & $\begin{array}{c}-0.31 \\
(0.06)^{* * *}\end{array}$ & $\begin{array}{c}-0.23 \\
(0.01)^{* * *}\end{array}$ & $\begin{array}{c}-0.27 \\
(0.07)^{* * *}\end{array}$ & $\begin{array}{c}-0.23 \\
(0.01)^{* * *}\end{array}$ & $\begin{array}{c}0.02 \\
(0.24)\end{array}$ & $\begin{array}{c}0.02 \\
(0.04)\end{array}$ & $\begin{array}{c}-0.43 \\
(0.13)^{* * *}\end{array}$ & $\begin{array}{c}-0.3 \\
(0.02)^{* * *}\end{array}$ & $\begin{array}{c}0.03 \\
(0.19)\end{array}$ & $\begin{array}{c}0.1 \\
(0.02)^{* * *}\end{array}$ & $\begin{array}{c}2.22 \\
(0.93)^{* *}\end{array}$ & $\begin{array}{c}0.22 \\
(0.09)^{* *}\end{array}$ \\
\hline 1990 & $\begin{array}{c}-0.37 \\
(0.06)^{* * *}\end{array}$ & $\begin{array}{c}-0.23 \\
(0.01)^{* * *}\end{array}$ & $\begin{array}{c}-0.36 \\
(0.07)^{* * *}\end{array}$ & $\begin{array}{c}-0.23 \\
(0.01)^{* * *}\end{array}$ & $\begin{array}{c}0.21 \\
(0.23)\end{array}$ & $\begin{array}{c}0.01 \\
(0.04)\end{array}$ & $\begin{array}{c}-0.68 \\
(0.12)^{* * *}\end{array}$ & $\begin{array}{c}-0.28 \\
(0.02)^{* * *}\end{array}$ & $\begin{array}{c}0.46 \\
(0.18)^{* *}\end{array}$ & $\begin{array}{c}0.07 \\
(0.02)^{* * *}\end{array}$ & $\begin{array}{c}2.82 \\
(1.39)^{* *}\end{array}$ & $\begin{array}{c}0.1 \\
(0.10)\end{array}$ \\
\hline 1991 & $\begin{array}{c}-0.26 \\
(0.06)^{* * *}\end{array}$ & $\begin{array}{c}-0.25 \\
(0.01)^{* * *}\end{array}$ & $\begin{array}{c}-0.27 \\
(0.07)^{* * *}\end{array}$ & $\begin{array}{c}-0.25 \\
(0.01)^{* * *}\end{array}$ & $\begin{array}{c}0.36 \\
(0.20)^{*}\end{array}$ & $\begin{array}{c}0.01 \\
(0.03)\end{array}$ & $\begin{array}{c}-0.57 \\
(0.12)^{* * *}\end{array}$ & $\begin{array}{c}-0.29 \\
(0.02)^{* * *}\end{array}$ & $\begin{array}{c}0.21 \\
(0.18)\end{array}$ & $\begin{array}{c}0.05 \\
(0.02)^{* *}\end{array}$ & $\begin{array}{c}-0.43 \\
(0.84)\end{array}$ & $\begin{array}{c}0.07 \\
(0.08)\end{array}$ \\
\hline 1992 & $\begin{array}{c}-0.59 \\
(0.06)^{* * *}\end{array}$ & $\begin{array}{c}-0.21 \\
(0.01)^{* * *}\end{array}$ & $\begin{array}{c}-0.61 \\
(0.06)^{* * *}\end{array}$ & $\begin{array}{c}-0.21 \\
(0.01)^{* * *}\end{array}$ & $\begin{array}{c}0.08 \\
(0.18)\end{array}$ & $\begin{array}{c}0.04 \\
(0.04)\end{array}$ & $\begin{array}{c}-0.85 \\
(0.12)^{* * *}\end{array}$ & $\begin{array}{c}-0.22 \\
(0.02)^{* * *}\end{array}$ & $\begin{array}{c}0.56 \\
(0.18)^{* * *}\end{array}$ & $\begin{array}{c}0.02 \\
(0.02)\end{array}$ & $\begin{array}{l}-0.08 \\
(1.13)\end{array}$ & $\begin{array}{c}0.06 \\
(0.07)\end{array}$ \\
\hline 1993 & $\begin{array}{c}-0.42 \\
(0.06)^{* * *}\end{array}$ & $\begin{array}{c}-0.23 \\
(0.01)^{* * *}\end{array}$ & $\begin{array}{c}-0.38 \\
(0.06)^{* * *}\end{array}$ & $\begin{array}{c}-0.24 \\
(0.01)^{* * *}\end{array}$ & $\begin{array}{c}0.05 \\
(0.21)\end{array}$ & $\begin{array}{c}0.07 \\
(0.04)^{* *}\end{array}$ & $\begin{array}{c}-0.5 \\
(0.12)^{* * *}\end{array}$ & $\begin{array}{c}-0.3 \\
(0.02)^{* * *}\end{array}$ & $\begin{array}{c}0.15 \\
(0.18)\end{array}$ & $\begin{array}{c}0.09 \\
(0.02)^{* * *}\end{array}$ & $\begin{array}{c}0.73 \\
(1.00)\end{array}$ & $\begin{array}{c}0.25 \\
(0.07)^{* * *}\end{array}$ \\
\hline 1994 & $\begin{array}{c}-0.39 \\
(0.06)^{* * *}\end{array}$ & $\begin{array}{c}-0.23 \\
(0.01)^{* * *}\end{array}$ & $\begin{array}{c}-0.37 \\
(0.06)^{* * *}\end{array}$ & $\begin{array}{c}-0.23 \\
(0.01)^{* * *}\end{array}$ & $\begin{array}{c}0.23 \\
(0.21)\end{array}$ & $\begin{array}{c}0.04 \\
(0.04)\end{array}$ & $\begin{array}{c}-0.62 \\
(0.13)^{* * *}\end{array}$ & $\begin{array}{c}-0.26 \\
(0.02)^{* * *}\end{array}$ & $\begin{array}{c}0.21 \\
(0.18)\end{array}$ & $\begin{array}{c}0.04 \\
(0.02)^{*}\end{array}$ & $\begin{array}{c}1.17 \\
(0.75)\end{array}$ & $\begin{array}{c}0.16 \\
(0.07)^{* *}\end{array}$ \\
\hline 1995 & $\begin{array}{c}-0.31 \\
(0.06)^{* * *}\end{array}$ & $\begin{array}{c}-0.26 \\
(0.01)^{* * *}\end{array}$ & $\begin{array}{c}-0.25 \\
(0.06)^{* * *}\end{array}$ & $\begin{array}{c}-0.27 \\
(0.01)^{* * *}\end{array}$ & $\begin{array}{l}-0.11 \\
(0.21)\end{array}$ & $\begin{array}{c}0.11 \\
(0.04)^{* * *}\end{array}$ & $\begin{array}{c}-0.26 \\
(0.12)^{* *}\end{array}$ & $\begin{array}{c}-0.29 \\
(0.02)^{* * *}\end{array}$ & $\begin{array}{c}0.06 \\
(0.18)\end{array}$ & $\begin{array}{c}0.04 \\
(0.02)\end{array}$ & $\begin{array}{c}0.51 \\
(1.09)\end{array}$ & $\begin{array}{c}0.03 \\
(0.07)\end{array}$ \\
\hline 1996 & $\begin{array}{c}-0.39 \\
(0.06)^{* * *}\end{array}$ & $\begin{array}{c}-0.26 \\
(0.01)^{* * *}\end{array}$ & $\begin{array}{c}-0.35 \\
(0.06)^{* * *}\end{array}$ & $\begin{array}{c}-0.26 \\
(0.01)^{* * *}\end{array}$ & $\begin{array}{c}0.21 \\
(0.22)\end{array}$ & $\begin{array}{c}0.11 \\
(0.04)^{* * *}\end{array}$ & $\begin{array}{c}-0.54 \\
(0.12)^{* * *}\end{array}$ & $\begin{array}{c}-0.31 \\
(0.02)^{* * *}\end{array}$ & $\begin{array}{c}0.25 \\
(0.17)\end{array}$ & $\begin{array}{c}0.08 \\
(0.02)^{* * *}\end{array}$ & $\begin{array}{l}-0.27 \\
(0.94)\end{array}$ & $\begin{array}{c}0.04 \\
(0.07)\end{array}$ \\
\hline 1997 & $\begin{array}{c}-0.3 \\
(0.06)^{* * *}\end{array}$ & $\begin{array}{c}-0.28 \\
(0.01)^{* * *}\end{array}$ & $\begin{array}{c}-0.26 \\
(0.06)^{* * *}\end{array}$ & $\begin{array}{c}-0.29 \\
(0.01)^{* * *}\end{array}$ & $\begin{array}{l}-0.11 \\
(0.22)\end{array}$ & $\begin{array}{c}0.03 \\
(0.04)\end{array}$ & $\begin{array}{c}-0.35 \\
(0.13)^{* * *}\end{array}$ & $\begin{array}{c}-0.33 \\
(0.02)^{* * *}\end{array}$ & $\begin{array}{c}0.2 \\
(0.19)\end{array}$ & $\begin{array}{c}0.06 \\
(0.02)^{* * *}\end{array}$ & $\begin{array}{l}-0.11 \\
(0.90)\end{array}$ & $\begin{array}{c}0.14 \\
(0.08)^{*}\end{array}$ \\
\hline 1998 & $\begin{array}{c}-0.42 \\
(0.07)^{* * *}\end{array}$ & $\begin{array}{c}-0.29 \\
(0.01)^{* * *}\end{array}$ & $\begin{array}{c}-0.36 \\
(0.07)^{* * *}\end{array}$ & $\begin{array}{c}-0.29 \\
(0.01)^{* * *}\end{array}$ & $\begin{array}{c}-0.2 \\
(0.23)\end{array}$ & $\begin{array}{c}0.11 \\
(0.04)^{* * *}\end{array}$ & $\begin{array}{c}-0.64 \\
(0.14)^{* * *}\end{array}$ & $\begin{array}{c}-0.39 \\
(0.02)^{* * *}\end{array}$ & $\begin{array}{c}0.05 \\
(0.20)\end{array}$ & $\begin{array}{c}0.14 \\
(0.03)^{* * *}\end{array}$ & $\begin{array}{c}0.37 \\
(0.85)\end{array}$ & $\begin{array}{c}0.17 \\
(0.09)^{* *}\end{array}$ \\
\hline 1999 & $\begin{array}{c}-0.7 \\
(0.06)^{* * *}\end{array}$ & $\begin{array}{c}-0.25 \\
(0.01)^{* * *}\end{array}$ & $\begin{array}{c}-0.7 \\
(0.07)^{* * *}\end{array}$ & $\begin{array}{c}-0.26 \\
(0.01)^{* * *}\end{array}$ & $\begin{array}{c}0.18 \\
(0.22)\end{array}$ & $\begin{array}{c}0.06 \\
(0.04)\end{array}$ & $\begin{array}{c}-0.94 \\
(0.13)^{* * *}\end{array}$ & $\begin{array}{c}-0.29 \\
(0.02)^{* * *}\end{array}$ & $\begin{array}{c}0.21 \\
(0.19)\end{array}$ & $\begin{array}{c}0.05 \\
(0.03)^{*}\end{array}$ & $\begin{array}{c}1.4 \\
(0.73)^{*}\end{array}$ & $\begin{array}{c}0.14 \\
(0.07)^{* *}\end{array}$ \\
\hline 2000 & $\begin{array}{c}-0.69 \\
(0.06)^{* * *}\end{array}$ & $\begin{array}{c}-0.25 \\
(0.01)^{* * *}\end{array}$ & $\begin{array}{c}-0.64 \\
(0.07)^{* * *}\end{array}$ & $\begin{array}{c}-0.25 \\
(0.01)^{* * *}\end{array}$ & $\begin{array}{l}-0.17 \\
(0.24)\end{array}$ & $\begin{array}{c}0.11 \\
(0.05)^{* *}\end{array}$ & $\begin{array}{c}-0.79 \\
(0.13)^{* * *}\end{array}$ & $\begin{array}{c}-0.27 \\
(0.02)^{* * *}\end{array}$ & $\begin{array}{c}0.2 \\
(0.19)\end{array}$ & $\begin{array}{c}0.03 \\
(0.03)\end{array}$ & $\begin{array}{c}0.65 \\
(0.60)\end{array}$ & $\begin{array}{c}0.14 \\
(0.08)^{*}\end{array}$ \\
\hline 2001 & $\begin{array}{c}-0.48 \\
(0.06)^{* * *}\end{array}$ & $\begin{array}{c}-0.28 \\
(0.01)^{* * *}\end{array}$ & $\begin{array}{c}-0.44 \\
(0.06)^{* * *}\end{array}$ & $\begin{array}{c}-0.28 \\
(0.01)^{* * *}\end{array}$ & $\begin{array}{l}-0.08 \\
(0.21)\end{array}$ & $\begin{array}{c}0.12 \\
(0.04)^{* *}\end{array}$ & $\begin{array}{c}-0.52 \\
(0.12)^{* * *}\end{array}$ & $\begin{array}{c}-0.38 \\
(0.02)^{* * *}\end{array}$ & $\begin{array}{c}0.24 \\
(0.18)\end{array}$ & $\begin{array}{c}0.16 \\
(0.02)^{* * *}\end{array}$ & $\begin{array}{c}0.1 \\
(0.61)\end{array}$ & $\begin{array}{c}0.43 \\
(0.09)^{* * *}\end{array}$ \\
\hline 2002 & $\begin{array}{c}-0.49 \\
(0.06)^{* * *}\end{array}$ & $\begin{array}{c}-0.26 \\
(0.01)^{* * *}\end{array}$ & $\begin{array}{c}-0.51 \\
(0.06)^{* * *}\end{array}$ & $\begin{array}{c}-0.26 \\
(0.01)^{* * *}\end{array}$ & $\begin{array}{c}0.11 \\
(0.24)\end{array}$ & $\begin{array}{c}-0.01 \\
(0.05)\end{array}$ & $\begin{array}{c}-0.71 \\
(0.11)^{* * *}\end{array}$ & $\begin{array}{c}-0.3 \\
(0.02)^{* * *}\end{array}$ & $\begin{array}{c}0.19 \\
(0.18)\end{array}$ & $\begin{array}{c}0.08 \\
(0.02)^{* * *}\end{array}$ & $\begin{array}{c}0.38 \\
(0.80)\end{array}$ & $\begin{array}{c}0.12 \\
(0.11)\end{array}$ \\
\hline 2003 & $\begin{array}{c}-0.57 \\
(0.06)^{* * *}\end{array}$ & $\begin{array}{c}-0.25 \\
(0.01)^{* * *}\end{array}$ & $\begin{array}{c}-0.57 \\
(0.07)^{* * *}\end{array}$ & $\begin{array}{c}-0.25 \\
(0.01)^{* * *}\end{array}$ & $\begin{array}{c}0.18 \\
(0.23)\end{array}$ & $\begin{array}{c}0.1 \\
(0.06)^{*}\end{array}$ & $\begin{array}{c}-0.78 \\
(0.11)^{* * *}\end{array}$ & $\begin{array}{c}-0.3 \\
(0.02)^{* * *}\end{array}$ & $\begin{array}{c}0.21 \\
(0.20)\end{array}$ & $\begin{array}{c}0.12 \\
(0.02)^{* * *}\end{array}$ & $\begin{array}{c}0.34 \\
(0.83)\end{array}$ & $\begin{array}{c}0.29 \\
(0.13)^{* *}\end{array}$ \\
\hline 2004 & $\begin{array}{c}-0.54 \\
(0.06)^{* * *}\end{array}$ & $\begin{array}{c}-0.24 \\
(0.01)^{* * *}\end{array}$ & $\begin{array}{c}-0.52 \\
(0.06)^{* * *}\end{array}$ & $\begin{array}{c}-0.25 \\
(0.01)^{* * *}\end{array}$ & $\begin{array}{c}0.05 \\
(0.24)\end{array}$ & $\begin{array}{c}0.12 \\
(0.06)^{* *}\end{array}$ & $\begin{array}{c}-0.88 \\
(0.10)^{* * *}\end{array}$ & $\begin{array}{c}-0.26 \\
(0.02)^{* * *}\end{array}$ & $\begin{array}{c}0.61 \\
(0.19)^{* * *}\end{array}$ & $\begin{array}{c}0.03 \\
(0.02)\end{array}$ & $\begin{array}{c}1.11 \\
(0.79)\end{array}$ & $\begin{array}{c}0.32 \\
(0.18)^{*}\end{array}$ \\
\hline 2005 & $\begin{array}{c}-0.59 \\
(0.06)^{* * *}\end{array}$ & $\begin{array}{c}-0.24 \\
(0.01)^{* * *}\end{array}$ & $\begin{array}{c}-0.6 \\
(0.06)^{* * *}\end{array}$ & $\begin{array}{c}-0.24 \\
(0.01)^{* * *}\end{array}$ & $\begin{array}{c}0.37 \\
(0.22)^{*}\end{array}$ & $\begin{array}{c}0.07 \\
(0.05)\end{array}$ & $\begin{array}{c}-0.93 \\
(0.10)^{* * *}\end{array}$ & $\begin{array}{c}-0.27 \\
(0.02)^{* * *}\end{array}$ & $\begin{array}{c}0.73 \\
(0.18)^{* * *}\end{array}$ & $\begin{array}{c}0.05 \\
(0.02)^{* *}\end{array}$ & $\begin{array}{c}0.45 \\
(0.93)\end{array}$ & $\begin{array}{c}0.1 \\
(0.14)\end{array}$ \\
\hline 2006 & $\begin{array}{c}-0.64 \\
(0.03)^{* * *}\end{array}$ & $\begin{array}{c}-0.28 \\
(0.01)^{* * *}\end{array}$ & $\begin{array}{c}-0.64 \\
(0.03)^{* * *}\end{array}$ & $\begin{array}{c}-0.28 \\
(0.01)^{* * *}\end{array}$ & $\begin{array}{c}0.19 \\
(0.13)\end{array}$ & $\begin{array}{c}0.07 \\
(0.03)^{* *}\end{array}$ & $\begin{array}{c}-0.75 \\
(0.05)^{* * *}\end{array}$ & $\begin{array}{c}-0.31 \\
(0.01)^{* * *}\end{array}$ & $\begin{array}{c}0.33 \\
(0.11)^{* * *}\end{array}$ & $\begin{array}{c}0.07 \\
(0.02)^{* * *}\end{array}$ & $\begin{array}{c}0.6 \\
(0.53)\end{array}$ & $\begin{array}{c}0.04 \\
(0.08)\end{array}$ \\
\hline 2007 & $\begin{array}{c}-0.64 \\
(0.04)^{* * *}\end{array}$ & $\begin{array}{c}-0.26 \\
(0.01)^{* * *}\end{array}$ & $\begin{array}{c}-0.65 \\
(0.04)^{* * *}\end{array}$ & $\begin{array}{c}-0.26 \\
(0.01)^{* * *}\end{array}$ & $\begin{array}{c}0.2 \\
(0.15)\end{array}$ & $\begin{array}{c}0.05 \\
(0.04)\end{array}$ & $\begin{array}{c}-0.82 \\
(0.07)^{* * *}\end{array}$ & $\begin{array}{c}-0.29 \\
(0.01)^{* * *}\end{array}$ & $\begin{array}{c}0.36 \\
(0.13)^{* * *}\end{array}$ & $\begin{array}{c}0.05 \\
(0.02)^{* *}\end{array}$ & $\begin{array}{c}1.09 \\
(0.32)^{* * *}\end{array}$ & $\begin{array}{c}0.2 \\
(0.06)^{* * *}\end{array}$ \\
\hline 2008 & $\begin{array}{c}-0.66 \\
(0.05)^{* * *}\end{array}$ & $\begin{array}{c}-0.25 \\
(0.01)^{* * *}\end{array}$ & $\begin{array}{c}-0.65 \\
(0.05)^{* * *}\end{array}$ & $\begin{array}{c}-0.25 \\
(0.01)^{* * *}\end{array}$ & $\begin{array}{c}0.21 \\
(0.18)\end{array}$ & $\begin{array}{c}0 \\
(0.04)\end{array}$ & $\begin{array}{c}-0.91 \\
(0.10)^{* * *}\end{array}$ & $\begin{array}{c}-0.29 \\
(0.01)^{* * *}\end{array}$ & $\begin{array}{c}0.3 \\
(0.14)^{* *}\end{array}$ & $\begin{array}{c}0.07 \\
(0.02)^{* * *}\end{array}$ & $\begin{array}{c}1.1 \\
(0.49)^{* *}\end{array}$ & $\begin{array}{c}0.17 \\
(0.07)^{* *}\end{array}$ \\
\hline 2009 & $\begin{array}{c}-0.65 \\
(0.05)^{* * *}\end{array}$ & $\begin{array}{c}-0.25 \\
(0.01)^{* * *}\end{array}$ & $\begin{array}{c}-0.64 \\
(0.05)^{* * *}\end{array}$ & $\begin{array}{c}-0.25 \\
(0.01)^{* * *}\end{array}$ & $\begin{array}{c}0.13 \\
(0.17)\end{array}$ & $\begin{array}{c}0.04 \\
(0.04)\end{array}$ & $\begin{array}{c}-0.94 \\
(0.12)^{* * *}\end{array}$ & $\begin{array}{c}-0.29 \\
(0.02)^{* * *}\end{array}$ & $\begin{array}{c}0.26 \\
(0.15)^{*}\end{array}$ & $\begin{array}{c}0.04 \\
(0.02)^{* *}\end{array}$ & $\begin{array}{c}0.42 \\
(0.43)\end{array}$ & $\begin{array}{c}0.17 \\
(0.05)^{* * *}\end{array}$ \\
\hline 2010 & $\begin{array}{c}-0.68 \\
(0.05)^{* * *}\end{array}$ & $\begin{array}{c}-0.25 \\
(0.01)^{* * *}\end{array}$ & $\begin{array}{c}-0.71 \\
(0.05)^{* * *}\end{array}$ & $\begin{array}{c}-0.24 \\
(0.01)^{* * *}\end{array}$ & $\begin{array}{c}0.65 \\
(0.17)^{* * *}\end{array}$ & $\begin{array}{l}-0.02 \\
(0.03)\end{array}$ & $\begin{array}{c}-0.63 \\
(0.13)^{* * *}\end{array}$ & $\begin{array}{c}-0.26 \\
(0.02)^{* * *}\end{array}$ & $\begin{array}{c}0.02 \\
(0.16)\end{array}$ & $\begin{array}{c}0.01 \\
(0.02)\end{array}$ & $\begin{array}{c}0.54 \\
(0.36)\end{array}$ & $\begin{array}{c}0.02 \\
(0.05)\end{array}$ \\
\hline
\end{tabular}

Standard errors in parentheses, ${ }^{*}$ significant at $10 \% ;{ }^{* *}$ significant at $5 \% ;{ }^{* * *}$ significant at $1 \%$ 
Figure 11 reports our calculations for the SMI for the two age brackets analyzed. They are best viewed graphically to appreciate the time variation. Andersen (2001) and Conconi et al. (2009) computed the SMI for several Latin American countries. Our results for the overall SMI are close to theirs. Both coincide in that they place Uruguay among the top three countries with the highest mobility in Latin America.

The SMI for mandatory education, between 6 and 15 years old, is very stable in the range, 0.89-0.93, for the whole period considered. Thus, according to this index, our results mean there would be no changes in mobility. This finding, however, must be tempered with the caveat that, as education is mandatory, family background becomes less important than institutional factors.

During the period considered, the SMI for non-mandatory education varies from 0.79 to 0.88 . It could be argued that for 16-23 year olds, family background loses importance as the individual gains autonomy. This would lower the importance of family variables in explaining educational outcomes. It can also be argued that for this group parents are neither pressed by the authorities nor given financial incentives, so there is no stigma for not sending children to school. Therefore, only those parents with a clear understanding of the importance of education will influence their children to continue their studies. An understanding of the importance of education is not the property of any single social group, but it probably correlates with better education and socioeconomic background of the parents. This increases the importance of family background as a determinant of educational outcomes. While the net effect of these two forces is ambiguous, we find that, in fact, the SMI for the age bracket 16-23 is smaller than for the younger group at conventional statistically significant levels for most of the years under study. This finding suggests that the second effect dominates.

We also found that the SMI for ages 16-23 shows a consistent decline during the period, reaching its minimum level in 2001, implying a decrease in the levels of social mobility in the country. This is in line with concerns about increased segmentation in Uruguayan society, and a worsening of the educational system as an opportunityequalizing device. During the last decade, however, social mobility in the case of nonmandatory education seems to have stabilized at about 0.80 and to have stopped its decline. 
Following Ferreira et al. (2010), we compute an Index of Inequality of Opportunity for mandatory and non-mandatory education and report it in Figure 12. It is simply the R-squared of the OLS regressions presented above. The idea is that the percentage of the SG that is explained by circumstances that do not depend on the child is a measure of the differences in opportunities among children. This index is different than the SMI in that it is not only concerned with family background variables; it also considers all circumstances that could affect a child's performance. While the set of family background characteristics included in our explanation of the SG can account for about 0.12 of its variance in mandatory education and is stable through the period of study, those characteristics account for about 0.25 in non-mandatory education, and show a tendency to increase over time. This is consistent with the SMI findings.

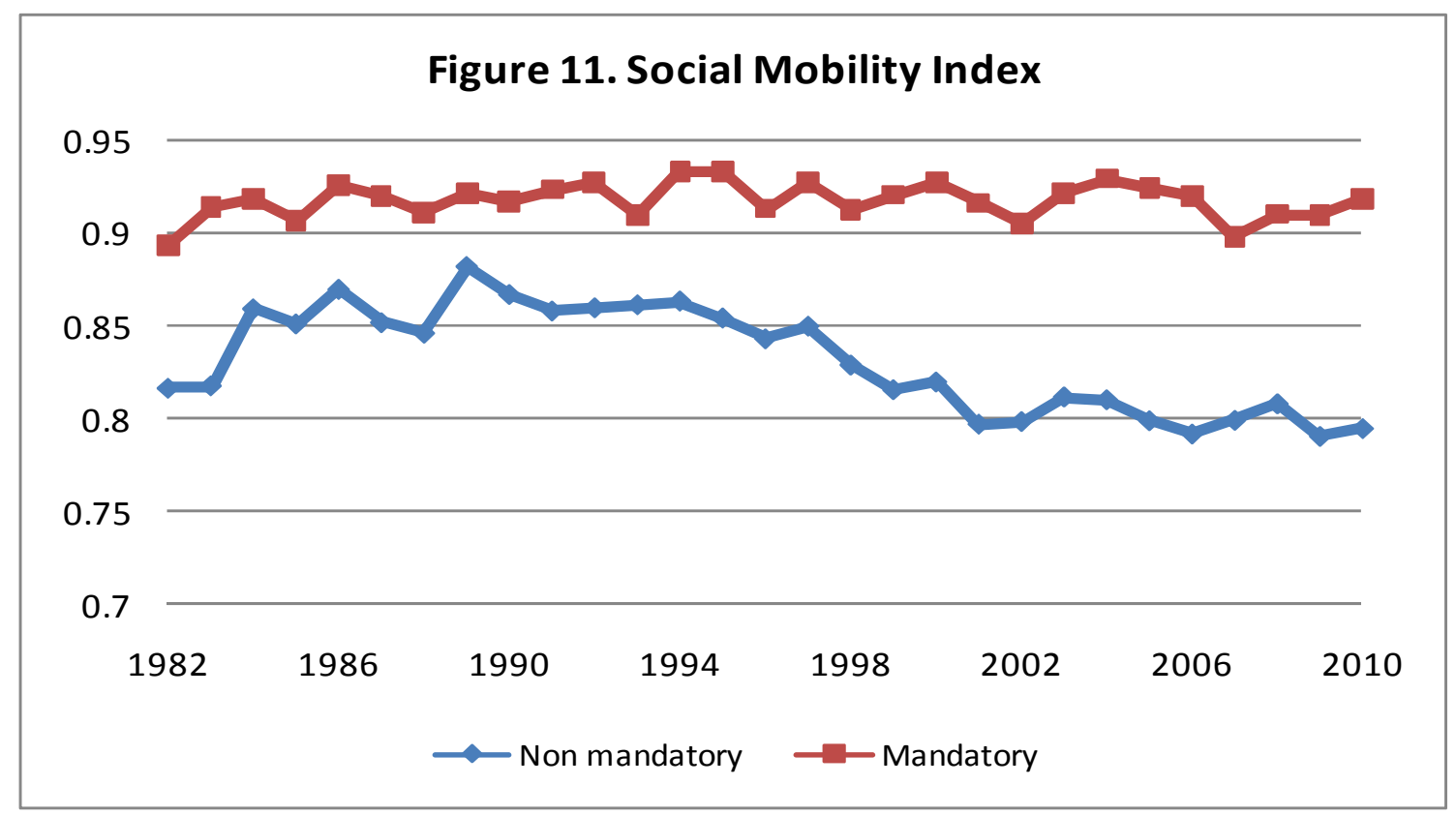




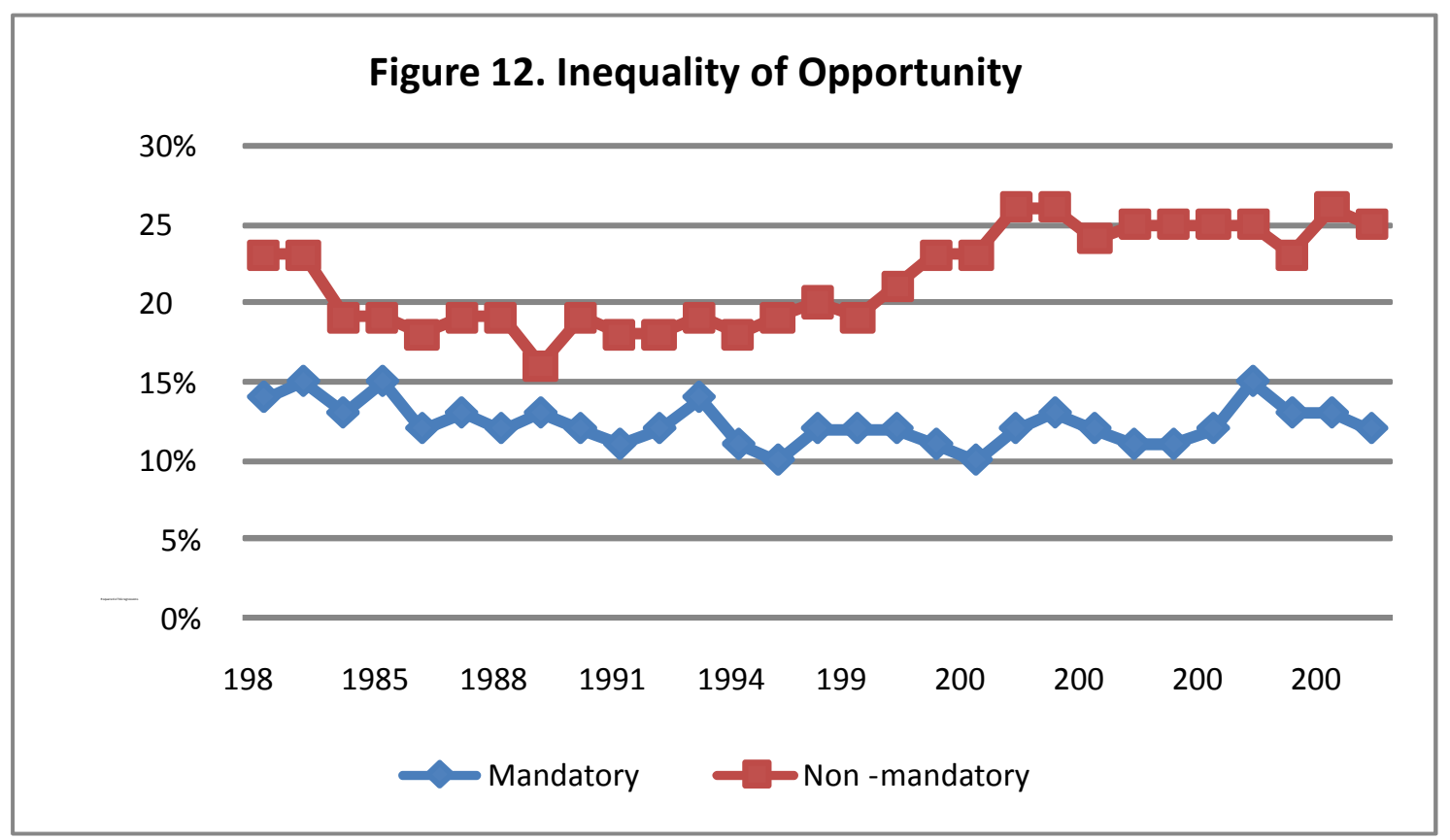

In Figure 13, we present the SMI for mandatory education for non-entrepreneurs and for entrepreneurs. As expected from the regression results, the mandatory education SMI is higher for entrepreneurs than for the rest of society. Even though mobility in Uruguay is higher when compared to the rest of Latin America, this estimation indicates that mobility for entrepreneurs is even higher.

Figure 14 presents the SMI for non-mandatory education for entrepreneurs and non-entrepreneurs. They both follow the same trend and they are not statistically different. Both for entrepreneurs and non-entrepreneurs, the SMI for non-mandatory education decreased in the 1990s and has not recovered since. In Figures 15 and 16, we present the SMI by social sector for mandatory and non-mandatory education, respectively. In Figure 15 we can see that the mandatory education SMI for the middle sector is much larger than the SMI for the affluent and disadvantaged sectors. Figure 16 shows that for non-mandatory education, the SMI for the middle sector is also larger than it is for the other sectors, but the differences are small and not statistically significant over many years. We expected to find more activity due to entrepreneurship or social sectors in the non-mandatory years of education. Contrary to our expectations, the results turned out to be stronger for the mandatory years. This suggests that making education mandatory is not sufficient to equalize opportunities. Quality differences persist that 
should be given priority. Defining the specific quality differentials is beyond the scope of this paper but is a necessary area for future research.
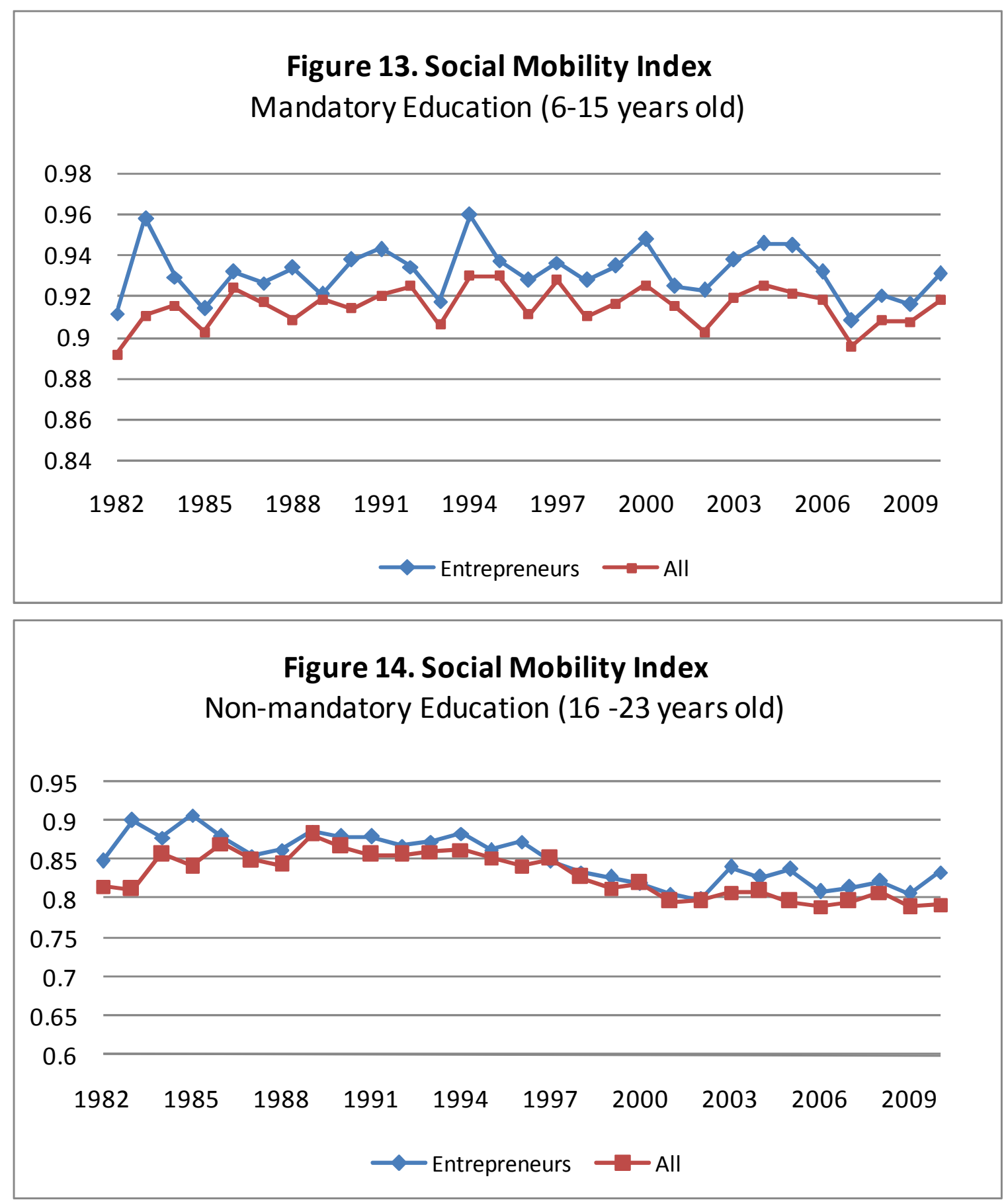

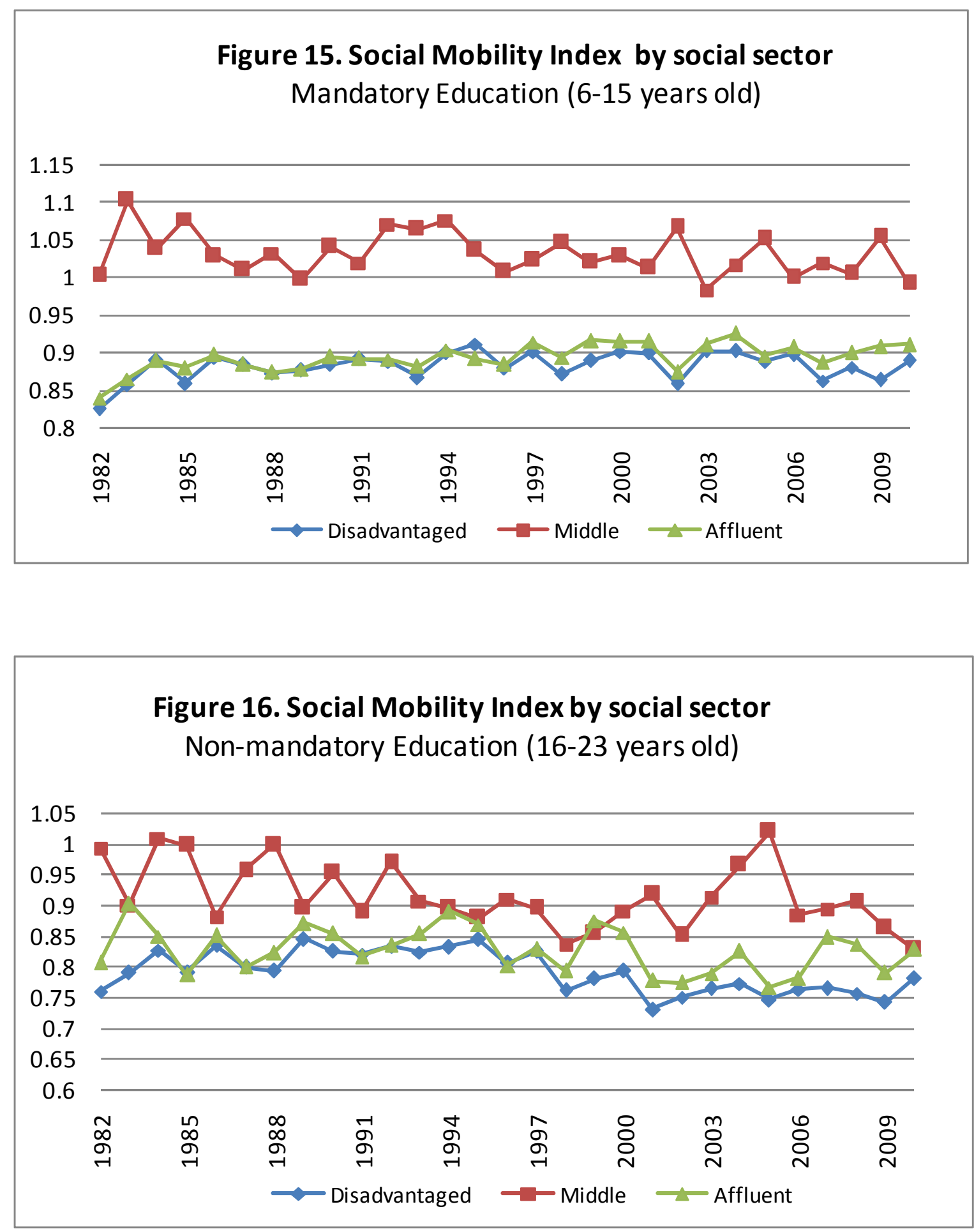


\section{Conclusions and Discussion}

In this paper we study the impact of parents' educational attainment and income on children's education in Uruguay between 1982 and 2010. We view educational mobility as a proxy for inter-generational social mobility.

The transition matrices computed show decreasing levels of mobility, where the less educated have increased probabilities that their children will also be among those with less education. On the other extreme, those with more education have increasing probabilities that their children will be among those more educated. Nevertheless, during the 1980s and 1990s, the steady-state distribution of educational attainment implied in the transition matrices showed an increase in the share of those who at least completed secondary education. This increase stagnated around 2005. Unfortunately, these improvements in access to higher education imply that most of the population will not complete secondary education, and the improvements are unevenly distributed among social sectors. Most of the increase in access to higher education is seen in the affluent and middle sectors, with almost no improvement in the disadvantaged sector.

We also computed an index of social mobility, which reflects how much of children's educational outcome, or SG, is explained by the parents' schooling and income. We found that while there were no changes in the index for mandatory education, there was a decrease, or lower mobility for non-mandatory education, i.e., the last three years of high school and university attendance. Therefore, the evidence suggests that inter-generational social mobility in Uruguay has lowered and there are risks of increased social segmentation. The overall picture suggests that during the mandatory education years, the Uruguayan public education system been an equalizing device. Beyond the mandatory years, the educational system evolved to produce a worsening in intergenerational mobility since the 1990s. This evidence, together with the transition matrices, suggests that the larger enrollment and retention problems are at the secondary education level.

Family background variables play a small role in determining educational outcomes for families of entrepreneurs and for middle sector families. Institutional and social pressures are stronger for mandatory education than for non-mandatory education. That is why we expected entrepreneurship and social sector to have stronger effects in the 
later years. Unexpectedly we found stronger results for mandatory education, i.e., families of entrepreneurs and middle sector have, compared to non-entrepreneurs and the disadvantaged sector, more impact on improving the mandatory education of their children than at higher levels. We conjecture that although the public school system in Uruguay successfully provides primary education for everybody and, to a lesser extent, the first years of secondary school, there are important differences in the quality of education for children of entrepreneurs and the middle sector.

Finally, looking at our results differently, entrepreneurship is indeed a channel for higher inter-generational social mobility, and mobility for the middle sector is also greater. This quantitative evidence affirms the anecdotal evidence of immigrantsindividuals scarcely educated but with tremendous creative spirit-who progressed, ascended socially, and provided better living conditions for their descendants. Although Uruguay long ago stopped receiving waves of immigrants, the potential of entrepreneurship as a mobility device is still there. 


\section{References}

Acemoglu, D. and F. Zilibotti. 1997."Was Prometheus Unbound by Chance? Risk, Diversification, and Growth.”Journal of Political Economy 105(4): 709-751.

Acs Z. 2006."How is Entrepreneurship Good for Economic Growth?." Innovations Journal Winter.

Andersen, L. E. 2001."Social Mobility in Latin America: Links with Adolescent Schooling." Inter-American Development Bank, Latin American Research Network. Working Paper R-433.

Araar, A. and J.-Y.Duclos. 2007. DASP: Distributive Analysis Stata Package. PEP, World Bank, UNDP, and Université Laval.

Azevedo, V. and C. Bouillon.2010. "Intergenerational Social Mobility in Latin America: A Review of Existing Evidence.” Revista de Análisis Económico 25(2): 7-42.

Banerjee, A. and E. Duflo. 2007. "What is Middle Class about the Middle Classes Around the World?". CEPR Discussion Papers 6613.

Behrman, J., N. Birdsall, and M. Székely. 1999. "Intergenerational Mobility in South America. Deeper Markets and Better Schools Make a Difference." in Nancy Bridsall and Caroll Graham (eds.) New Markets, New Opportunities?: Economic and Social Mobility in a Changing World. Washington, DC, United States: Brooking Institution and Carnegie Endowment for International Peace.

Bukstein, D. and C. Sapelli. 2011. "Educación y Crecimiento". BCU Working Paper Series.

Bukstein D. and N.Gandelman. 2011. "Intra-generational Social Mobility and Entrepreneurship in Uruguay". Unpublished manuscript.

Conconi A., G. Cruces, S. Olivieri, and R. Sánchez.2007."E pursimuove? Movilidad, Pobreza y Desigualdad en América Latina.” CEDLAS Working Paper, 62.

Esteban, J., C. Gardín, and D. Ray. 1999. "Extensions of the Measure of Polarization, with an Application to the Income Distribution of Five OECD Countries." Mimeographed paper. Instituto de Análisis Económico. 
Fields, G. S. 2003. “Accounting for Income Inequality and its Change: A New Method, with Application to the Distribution of Earnings in the United States." Research in Labor Economics 22: 1-38.

Haveman, R. and B. Wolfe. 1995. "The Determinants of Children's Attainments: A Review of Methods and Findings." Journal of Economic Literature 33(4): 18291878.

Holmlund, H., M. Lindahl, and E. Plug. 2011. "The Causal Effect of Parent's Schooling on Children's Schooling.” Journal of Economic Literature 49(3): 615-651.

Lopez-Calva, L. and E. Ortiz-Juarez. "A Vulnerability Approach to the Definition of the Middle Class.” The World Bank. Policy Research Working Paper 5902.

OECD. 2011. Latin American Economic Outlook. OECD Development Centre.

Shorrocks, Anthony F. 1982. "Inequality Decomposition by Factor Components." Econometrica 50: 193-211.

Vega, E. and J.Petrow. 2008. Raising Student Learning in Latin America. The World Bank. 